\title{
THE CITY SPEAKS: CITIES, CITIZENS, AND CIVIC DISCOURSE IN LATE ANTIQUITY AND THE EARLY MIDDLE AGES
}

\author{
BY MEGAN WELTON
}

This article investigates how civic discourse connects the virtue of citizens and the fortunes of cities in a variety of late antique and early medieval sources in the postRoman west. It reveals how cities assume human qualities through the rhetorical technique of personification and, crucially, the ways in which individuals and communities likewise are described with civic terminology. It also analyzes the ways in which the city and the civic community are made to speak to one another at times of crisis and

This article is a result of the project NWO VICI-Rose 277-30-002 Citizenship Discourses in the Early Middle Ages, 400-1100, funded by the Netherlands Organisation for Scientific Research (NWO). I would like to thank our entire project team, and especially Els Rose, for reading and providing invaluable comments on several previous drafts of this article. Furthermore, I thank Tom Noble for his astute comments on an earlier draft of this article, as well as the anonymous reviewers at Traditio for their many perceptive critiques and comments.

The following abbreviations are used in the notes of this article:

$B P U=$ Abbo of St-Germain, Bella Parisiacae Urbis, ed. P. von Winterfeld in MGH, Poetae 4.1 (Berlin, 1899), 77-121; trans. A. Adams and A. G. Rigg, "A Verse Translation of Abbo of St. Germain's Bella Parisiacae urbis," Journal of Medieval Latin 14 (2004): 1-68, cited by chapter and/or line(s) and page number(s).

$L P=$ Liber Pontificalis, in Le Liber Pontificalis: Texte, introduction et commentaire, vol. 2, ed. L. Duchesne, (Paris, 1892); trans. R. Davis, The Lives of Ninth-Century Popes (Liber Pontificalis) (Liverpool, 1995), cited by chapter and/or line(s) and page number(s).

Passio Pelagii = Hrotsvitha of Gandersheim, Passio sancti Pelagii preciosissimi martyris, qui nostris temporibus in Corduba martirio est coronatus, in Hrotsvit Opera Omnia, ed. W. Berschin, Biblioteca Teubneriana (Leipzig, 2001).

Psychomachia $=$ Prudentius, Psychomachia, ed. M. P. Cunningham, Aurelii Prudentii Clementis Carmina, CCL 126 (Turnhout, 1966), 149-181; trans. H. J. Thomson, Loeb Classical Library (hereafter LCL) 387 (Cambridge, MA, 1949), cited by chapter and/or line(s) and page number(s).

Peristephanon $=$ Prudentius, Liber Peristephanon, ed. M. P. Cunningham, Aurelii Prudentii Clementis Carmina, CCL 126 (Turnhout, 1966), 251-389; trans. L. Krisak, Prudentius' Crown of Martyrs: Liber Peristephanon (London, 2019), cited by chapter and/or line(s) and page number(s).

$V M C=$ Versum de Mediolano civitate, ed. G. B. Pighi, Versus de Verona. Versum de Mediolano civitate (Bologna, 1960).

VV = Versus de Verona, ed. G. B. Pighi, Versus de Verona. Versum de Mediolano civitate (Bologna, 1960).

\section{Traditio 75 (2020), 1-37}

(C) Fordham University 2020. This is an Open Access article, distributed under the terms of the Creative Commons Attribution-NonCommercial-NoDerivatives licence (http://creativecommons. org/licenses/by-nc-nd/4.0/), which permits non-commercial re-use, distribution, and reproduction in any medium, provided the original work is unaltered and is properly cited. The written permission of Cambridge University Press must be obtained for commercial re-use or in order to create a derivative work. 
celebration. By examining a diverse range of sources including epideictic poetry, chronicles, hagiographies, and epigraphic inscriptions, this article addresses multiple modes of late antique and early medieval thought that utilize civic discourse. It first explores how late antique and early medieval authors employed civic discourse in non-urban contexts, including how they conceptualized the interior construction of an individual's mind and soul as a fortified citadel, how they praised ecclesiastical and secular leaders as city structures, and how they extended civic terminology to the preeminently non-urban space of the monastery. The article then examines how personified cities spoke to their citizens and how citizens could join their cities in song through urban procession. Civic encomia and invective further illustrate how medieval authors sought to unify the virtuous conduct of citizens with the ultimate fate of the city's security. The article concludes with a historical and epigraphic case study of two programs of mural construction in ninth-century Rome. Ultimately, this article argues that the repeated and emphatic exhortations to civic virtue provide access to how late antique and early medieval authors sought to intertwine the fate of the city with the conduct of her citizens, in order to persuade their audiences to act in accordance with the precepts of virtue.

"Cities are praised in a manner similar to men." So wrote the Roman rhetorician Quintilian in his Institutio oratoria. In Book III of that work, Quintilian surveyed the principles of epideictic rhetoric, identifying appropriate objects for praise or blame, and setting out the criteria by which such evaluative judgments should be made. ${ }^{2}$ After sketching proper grounds for praising gods and men, Quintilian turned to the praise of cities. "The founder stands for the father," he wrote, "age gives authority [...] and the virtues and vices seen in actions are the same as those of individuals." 3 "The only particular features" of cities, he concluded, "are those which come from the site and the fortifications." ${ }^{\circ}$ Quintilian's Institutio oratoria had a considerable impact on medieval education and rhetorical composition. ${ }^{5}$ Numerous early medieval authors produced poetic panegyrics to cities that exemplified some or all of his precepts. ${ }^{6}$ While

1 Quintilian, Institutio oratoria 3.7: "Laudantur autem urbes similiter atque homines," ed. and trans. D.A. Russell, LCL 125 (Cambridge, 2002), 114-15.

2 Quintilian, Institutio oratoria 3.7, ed. and trans. Russell, 114-15.

3 Quintilian, Institutio oratoria 3.7, ed. and trans. Russell, 114-15: "Nam pro parente est conditor, et multum auctoritatis adfert vetustas [. . . et virtutes ac vitia circa res gestas eadem quae in singulis."

4 Quintilian, Institutio oratoria 3.7, ed. and trans. Russell, 114-15: "illa propria quae ex loci positione ac munitione sunt" (with slight emendations to the translation).

5 J. Ward, "Quintilian and the Rhetorical Revolution of the Middle Ages," Rhetorica 13 (1995): 231-84; N. van Deusen, "Cicero through Quintilian's Eyes in the Middle Ages," in Cicero Refused to Die: Ciceronian Influence through the Centuries, ed. eadem (Leiden, 2013), 47-63; and J. Ward, Classical Rhetoric in the Middle Ages: The Medieval Rhetors and their Art 400-1300, with Manuscript Survey to 1500 CE (Leiden, 2018). For the late antique and early medieval manuscript transmission of the Institutio oratoria, see M. Winterbottom, "Quintilian," in Texts and Transmission: A Survey of the Latin Classics, ed. L. D. Reynolds and N. G. Wilson (Oxford, 1983), 332-34.

6 See, amongst others, J. K. Hyde, "Medieval Descriptions of Cities," Bulletin of the John Rylands Library 48 (1965): 308-40; C. J. Classen, Die Stadt im Spiegel der Descriptiones und 
many scholars have examined the classical structures and topoi comprising the genre known as laudes urbium, Quintilian's particular comparison between the praise of cities and the praise of men remains largely unexplored. ${ }^{7}$ Furthermore, the integral link between the virtues of cities and those of citizens transcends the context of late antique and early medieval rhetorical education, finding expression in a much broader range of sources including hagiographies, hymns, annals, letters, and epigraphic inscriptions.

This study uncovers the connections between the conduct of citizens and the fortunes of cities instantiated in late antique and early medieval civic discourse, with a geographic focus on the kingdoms that comprised western Europe. ${ }^{8}$ The virtutes et vitia of individuals and cities were the same, as Quintilian suggests, because a virtuous citizenry was considered a necessary condition for the virtues of the city itself. Indeed, even the walls or fortifications, which Quintilian took to be peculiar to cities, develop within this discourse into physical indices of the relative virtue of citizens. As the defensive and defining structures of the early medieval civitas, walls and fortifications echoed the triumphs and tribulations of virtuous or fallen citizens.

Civic discourse appears in the first place in the classical and late antique terminology used to describe the city and its citizens. ${ }^{9}$ Grounded in both the

Laudes Urbium in der antiken und mittelalterlichen Literatur bis zum Ende des zwölften Jahrhunderts, Beiträge zur Altertumswissenschaft 2 (Hildesheim, 1980); E. Occhipinti, "Immagini di città: Le 'laudes civitatum' e la rappresentazione dei centri urbani nell'Italia settentrionale," Societa e Storia 51 (1991): 23-52; J. Ruth, Urban Honor in Spain: The Laus Urbis from Antiquity through Humanism (Lewiston, 2011); T. Granier, "À rebours des laudes ciuitatem: Les Versus Romae et le discours sur la ville dans l'Italie du haut Moyen Âge," in Le médiéviste devant ses sources: Questions et méthodes, ed. C. Carozzi and H. Taviani-Carozzi (Aix-en-Provence, 2004), 131-54; and P. Oldfield, Urban Panegyric and the Transformation of the Medieval City, 1100-1300 (Oxford, 2019).

7 For a survey and critique of the several terms denoting laudes urbium, see P. Zanna, "Descriptiones urbium' and Elegy in Latin and Vernaculars in the Early Middle Ages: At the Crossroads Between Civic Engagement, Artistic Enthusiasm and Religious Mediation," Studi Medievali 32 (1991): 523-96.

8 By civic discourse, I mean the terminology and iconography that late antique and early medieval authors and artists used to denote the city and the citizen. This focus on civic discourse permits this article to sidestep the much-debated question of what citizenship as a legal, political, and ethnic identity meant during Late Antiquity (particularly after the Antonine Constitution of 212) and in the Middle Ages. For recent research on these aspects of civic or urban identity and citizenship as well as relevant bibliography, see R. Mathisen, "Peregrini, Barbari, and Cives Romani: Concepts of Citizenship and the Legal Identity of Barbarians in the Later Roman Empire," American Historical Review 111 (2006): 1011-40; M. R. Prak, Citizens without Nations: Urban Citizenship in Europe and the World, c. 10001789 (Cambridge, 2018); and J. Martínez Jiménez, "Urban Identity and Citizenship in the West Between the Fifth and Seventh Centuries," Al-Masāq 32 (2020): 87-108.

9 My use of civic discourse in this paper is informed by discourse analysis set out by, among others, Pierre Bourdieu and Michel Foucault, but remains closely tied to the words 
Roman and biblical inheritance, key terms such as civitas, cives, urbs, murus, and moenia occur across a wide range of texts, from hagiographical narratives of saints warding off threats to their cities to laws denoting who can and cannot dwell within the city walls. ${ }^{10}$ These same terms pepper panegyrics praising citizens and cities for their virtuous actions, and color invectives condemning other cities for dwelling in vice. The concepts and models central to civic discourse also surface in early medieval images, from personified civitates flanking early medieval kings and emperors to manuscript illuminations depicting the biblical cities of Jerusalem and Bethlehem.

Yet civic discourse does not only refer to the terminology and iconography transmitted from the classical and biblical past into late antique and early medieval contexts. Just as importantly, it encompasses the words and phrases, hymns and prayers ascribed to citizens and even, at times, attributed to cities themselves. In order to understand how the city speaks, we must attend to all of its voices. This study will explore how civic discourse in late antique and early medieval texts describing the city, as well as epigraphic inscriptions carved onto the fabric of the city, both incorporated an inherited language and found striking ways to convey that language into the mouths of cities and citizens.

Any discussion of the early medieval civitas, cives, and civic discourse raises fundamental questions about the nature and survival not only of these terms, but also of the physical city itself. Scholars have long debated the extent to which cities declined throughout the transformation of the western Roman Empire into early medieval kingdoms, and whether — particularly outside the Italian peninsula — civic identity or civic consciousness persisted. ${ }^{11}$ One major area in

and images in extant late antique and medieval sources. The scholarship on discourse analysis and its intersection with historical inquiry is vast. Among others, see P. Bourdieu, Outline of a Theory of Practice, trans. R. Nice (Cambridge, 1977); and M. Foucault, The Order of Things: An Archaeology of the Human Sciences (New York, 1971). For recent analyses of Bourdieu and the field of history, see the collected articles in Bourdieu and Historical Analysis, ed. P. Gorski (Durham, 2013).

10 See, for instance, R. Flierman and E. Rose, "Banished from the Company of the Good: Christians and Aliens in Fifth-Century Rome," Al-Masāq 32 (2020): 64-86. For saints defending the city, see n. 16.

11 Among the vast scholarship on this issue, see A. Verhulst, "The Origins and Early Development of Medieval Towns in Northern Europe," Economic History Review 47 (1994): 362-73; J. H. W. G. Liebeschuetz, The Decline and Fall of the Roman City (Oxford, 2001); The Idea and Ideal of the Town between Late Antiquity and the Early Middle Ages, ed. G. P. Brogiolo and B. Ward-Perkins (Leiden, 2003); and C. Wickham, Framing the Early Middle Ages: Europe and the Mediterranean, 400-800 (Oxford, 2005), 591-673. For a recent exploration and historiographical survey of civic consciousness, see Oldfield, Urban Panegyric (n. 6 above), 8-11 and 23-26. For explorations of early medieval Italian civic consciousness, see Occhipinti, "Immagini di citta" (n. 6 above), 23-52; D. Romagnoli, "La coscienza civica nella città comunale italiana: La testimonianza delle laudes civitatum e il caso di Milano," in El mercat: Un món de contactes $i$ intercanvis, ed. F. Sabaté (Lleida, 2014), 57- 
which this debate has played out concerns the comparative upkeep or neglect of city walls. As a means of fortification and delimitation, city walls remained a crucial feature of urban life throughout Late Antiquity and the early Middle Ages. ${ }^{12}$ Indeed, few architectural features were so diligently maintained during the transition from the Roman Empire to the early medieval world. ${ }^{13}$ Italian city walls, often initially constructed or extensively reconstructed between the late third and early fifth centuries, "were repaired continuously through and beyond the Lombard period, becoming one of the most distinctive physical and psychological features of postclassical urbanism." 14 Even with the significant decline of manufactured goods and technical architectural standards characteristic of the seventh century, archaeologists have demonstrated that "selected elements of the monumental patrimony inherited from the past, notably city walls," continued to be kept up. ${ }^{15}$

While the physical context of urban fortifications is crucial, it is equally important to recognize the political, spiritual, and symbolic aspects of these same structures in this period. Saints, for example, often cast as protectors of individual cities, were even at times depicted as patrolling city walls, thus providing ideal exempla for ordinary citizens to emulate. ${ }^{16}$ More crucially, the collective body of citizens sheltered by city walls were implored regularly to gather together at times of crisis and of celebration to praise their city and its saints, or to pray for deliverance from imminent demise. ${ }^{17}$

76; and Urban Identities in Northern Italy (800-1100 ca.), ed. C. La Rocca and P. Majocchi (Turnhout, 2015).

12 R. Coates-Stephens, "The Walls and Aqueducts of Rome in the Early Middle Ages, A. D. 500-1000," Journal of Roman Studies 88 (1998): 166-78; and H. Dey, The Aurelian Wall and the Refashioning of Imperial Rome, AD 271-855 (Cambridge, 2011). For a recent exploration of the Italian epigraphic context surrounding walls and relevant historiography, see P. Guerrini, "Scrivere sulle mura: Le iscrizioni dei sistemi difensivi nella penisola italiana tra VI e XIII secolo: Note preliminari," Temporis Signa 8 (2013): 1-38.

13 As Trout has recently underscored, "many Italian towns and cities assiduously maintained their Imperial or late Roman walls down through the Carolingian age." See D. Trout, "Theodelinda's Rome: 'Ampullae,' 'Pittacia,' and the Image of the City," Memoirs of the American Academy in Rome 50 (2005): 131-50, at 135. See also Dey, The Aurelian Wall.

14 Trout, "Theodelinda's Rome," 135.

15 H. Dey, The Afterlife of the Roman City: Architecture and Ceremony in Late Antiquity and the Early Middle Ages (Cambridge, 2014), 135.

16 See, for instance, Prudentius's Passio Agnetis, the fourteenth hymn of his Liber Peristephanon, which starts with the lines: "Agnes sepulcrum est Romulea in domo / fortis puellae martyris inclytae. / Conspectu in ipso condita turrium / seruat salutem uirgo Quiritium / nec non et ipsos protegit aduenas / puro ac fideli pectore supplices." See Peristephanon 14, 1.1-6, ed. Cunningham, 386; trans. Krisek, 338-39. For a city's saint patrolling the walls (although in a vision), see $B P U, 2.119-25,101$.

17 See below. 
Tracing this robust civic discourse will take us through several crucial arenas of late antique and early medieval thought. The first section of this article focuses on the most interior, and most figurative, strains of civic discourse: those pertaining to the construction of the individual's mind and soul. Here I examine the motif of the mind as a fortified citadel, the casting of ecclesiastical and secular leaders as city walls, and the extension of civic terminology to preeminently non-urban places, such as monasteries. The second section analyzes how cities could be granted human qualities through the rhetorical technique of personification and considers how the personified city and its saints could serve to encourage citizens to virtuous action and praise, particularly through urban processions. The third section turns to civic encomia and invectives, showing how these exhortatory texts tied the virtues and vices of citizens to the maintenance or neglect of city walls. The fourth and final section presents a historical and epigraphical case study of Pope Leo IV's two programs of mural construction in ninth-century Rome.

\section{“The Virtues Enter the City:” Constructions of Civic Virtue in Late Antiquity and the Early Middle Ages}

Late antique and early medieval authors twinned civic discourse with virtus in numerous contexts. Readers and auditors were urged to fortify their minds; secular and ecclesiastic leaders were cast as city walls or other defensive structures; even preeminently non-urban spaces, such as monasteries, at times were cloaked in civic terminology. An initial survey of the extension of the terms of civic discourse in this period will establish just how deeply calls for citizens to practice virtus could resonate.

Late antique and early medieval authors often referred to the mind as an arx virtutum, which must constantly be defended lest vitia creep in. The mind-as-citadel motif has antique roots, tracing back to Cicero's explication of the Platonic division of the tripartite soul governed by reason placed "in the head as in the citadel." 18 In the fifth century, Augustine of Hippo wove this classical motif into the fourteenth book of his De civitate Dei, suggesting that "those philosophers" came close to truth in their assessment that the third part of the soul resides "in a kind of citadel, to rule the other parts, so that, with reason in command and the other parts serving it, justice be preserved as between all the parts of man's soul."19

18 Cicero, Tusculanae Disputationes 1.20: "eius doctor Plato triplicem finxit animum, cuius principatum, id est rationem, in capite sicut in arce posuit, et duas partes parere voluit, iram et cupiditatem, quas locis disclusit: iram in pectore, cupiditatem supter praecordia locavit," ed. M. Pohlenz, Tusculanae Disputationes (Leipzig, 1918), 227-28, trans. J. Davie, Cicero: On Life and Death (Oxford, 2017), 15 (with slight emendations).

19 Augustine, De civitate Dei 14.19: "velut in arce quadam ad istas regendas perhibent conlocatam, ut illa imperante, istis servientibus possit in homine iustitia ex omni animi parte servari," ed. B. Dombart and A. Kalb, CCL 47-48 (Turnhout, 1955), 441; trans. R. W. Dyson, Augustine: The City of God against the Pagans (Cambridge, 1998), 618. 
An arx signified not only command, but also safety — whether for the physical or figurative city. According to Bishop Isidore of Seville (d. 636) in his immensely influential Etymologiae, "citadels (arces) are the high, fortified parts of a city, for whatever are the safest places in a city are called citadels from their holding off (arcere) the enemy." 20 One of the chief enemies of the mind, for the fifthcentury monk John Cassian, was the vice of pride. After comparing pride to a pestilence that destroys the entire body, Cassian declares that pride takes possession of one's mind, "as if a most savage tyrant, having captured the loftiest citadel of the virtues, utterly destroys and lays waste the entire city." 21

Pope Gregory the Great (d. 604) capitalized on this metaphor of the mind as a fortified city in his own discussion about virtue and vice. In his Regula pastoralis, Gregory addressed the dangers of extremes of speech — either talking too much or absolute silence - through biblical exegesis. Discussing "those who spend time in much speaking," Gregory cited Proverbs 25:28, which states that "As a city that lieth open and is not compassed with walls, so is a man that cannot refrain his own spirit in speaking." 22 Gregory builds upon this metaphor, arguing that "because it has not the wall of silence, the city of the mind lies open to the darts of the foe." 23 Walls, for Gregory, could also signify virtues themselves. In his condemnation of the vice of gluttony, Gregory builds upon the verse in 2 Kings 25:10, which states "the chief of the cooks broke down the walls of Jerusalem." ${ }^{24}$ For Gregory, the walls of Jerusalem "are the virtues of the soul, elevated to a longing for supernal peace," while the chief of cooks symbolizes the vice of gluttony "because when the belly is held in gluttony, the virtues of the soul are destroyed through lust." 25

20 Isidore, Etymologiae 15.2.32: "Arces sunt partes urbis excelsae atque munitae. Nam quaecumque tutissima urbium sunt, ab arcendo hostem arces vocantur," ed. W. M. Lindsay (Oxford, 1911), 161; trans. S. A. Barney et. al., The Etymologies of Isidore of Seville (Cambridge, 2006), 307.

21 John Cassian, Institutiones coenobiorum et de octo principalium vitiorum remediis 12.3: "ut quidam saevissimus tyrannus, sublimissima capta arce virtutum, universam funditus civitatem diruit atque subvertit," ed. J.-C. Guy, Jean Cassien, Institutions cénobitiques, SC 109 (Paris, 1965), 452.

22 Gregory, Regula pastoralis 3.14: "Vnde scriptum est: Sicut urbs patens et absque murorum ambitu, ita uir qui non potest in loquendo cohibere spiritum suum," ed. B. Judic and F. Rommel, in Grégoire le Grand, Règle pastorale, SC 382 (Paris, 1992), 2:346; trans. G. E. Demacopoulos, St. Gregory the Great: The Book of Pastoral Rule (Crestwood, 2007), 123-24.

${ }^{23}$ Gregory, Regula pastoralis 3.14: "Quia enim murum silentii non habet, patet inimici iaculis ciuitas mentis," ed. Judic and Rommel, 2:346; trans. Demacopoulos, 123-24.

242 Kings 25:10: "princeps coquorum destruxit muros hierusalem." The phrase princeps coquorum occurs only in the Old Latin version of the Septuagint, while the Vulgate translates this phrase as princeps militum. See M. Manca, "Nabuzardan princeps coquorum: Una lezione vulgata oltre la Vulgata," in Quaderni del Dipartimento di Filologia Linguistica e Tradizione Classica (Torino) 13 (Torino, 1999), 491-98.

25 Gregory, Regula pastoralis 3.19: "quia dum uenter ingluuie tenditur, uirtutes animae per luxuriam destruuntur," ed. Judic and Rommel, 2:374; trans. Demacopoulos, 136-37. 
The metaphor of the fortified mind, and the perilous consequences of any breach by vice, recurred throughout early medieval texts. In biblical commentaries, this particular exegetical reading from the Regula Pastoralis appeared in seventh-century Northumbria with Bede's Super parabolas Salomonis allegorica expositio as well as in ninth-century Francia with Hrabanus Maurus's Expositio in proverbia Salomonis. ${ }^{26}$ Yet, this metaphor was not confined to the exegetical sphere. Indeed, late antique authors' instrumentalization of this metaphor of the mind as an enclosed fortress finds expression in Old English poems, including the Juliana and Vainglory. ${ }^{27}$ Both of these poems characterize the mind as a fortress, which can come under attack from the devil through the vices if not well fortified by the virtues. In Vainglory, the anonymous poet contrasts the virtuous with the vicious, the latter of whom is controlled by the sin of pride. The poet describes the mind of a prideful man as one that has "let missiles of deceit / shatter that citywall (burgweal) which God commended to him / in order that he should defend that rampart." 28 Whether in exegesis or poetry, each of these authors drew on a shared civic discourse, speaking across the conventions of genre and encouraging their readers to fortify their own minds.

Along with walls and citadels, late antique and early medieval authors utilized another fortified structure, the castrum, to signify mental fortifications in relation to virtues and vices. Perhaps the most eloquent example appears in the Psychomachia written by the fifth-century Iberian lawyer-turned-bishop Prudentius. ${ }^{29}$ In

26 Bede, Super parabolas Salomonis allegorica expositio 3.15, PL 91.1015C; and Hrabanus Maurus, Expositio in proverbia Salomonis 3.25, PL 111.765B.

27 The sole witness of both poems has been transmitted in the tenth-century collection of poems and riddles known as the Exeter Book: Exeter, Exeter Cathedral Library, MS 3501, fols. $65 \mathrm{v}-76 \mathrm{r}$ and fols. $83 \mathrm{r}-84 \mathrm{v}$. For a further exploration of the allegorical use of the mind and/or soul as fortress in Old English poetry, see J. F. Doubleday, "The Allegory of the Soul as Fortress in Old English Poetry," Anglia 88 (1970): 503-508; C. A. Regan, "Patristic Psychology in the Old English Vainglory," Traditio 26 (1970): 324-35, at 331; and B. Mize, "The Representation of the Mind as an Enclosure in Old English Poetry," Anglo-Saxon England 35 (2006): 57-90, at 81-89.

28 Vainglory, lines 37-39: "læted inwitflan / brecan pone burgweal, pe him bebead meotud / pæt he pæt wigsteal wergan sceolde." For a recent analysis, edition, and translation, see R. Proctor, "An Edition of Vainglory," in Leeds Studies in English, New Series 43, ed. A. Hall (Leeds, 2012), 51-73, at 70-71.

29 M. Smith, Prudentius' Psychomachia: A Reexamination (Princeton, 1976); and C. O'Hogan, Prudentius and the Landscapes of Late Antiquity (Oxford, 2016), 71-98. For the wider reception of the Psychomachia, see G. Wieland, "Aldhelm's De octo vitiis principalibus and Prudentius' Psychomachia," Medium Evum 55 (1986): 85-92; idem, "The Origin and Development of the Anglo-Saxon Psychomachia Illustrations," Anglo-Saxon England 26 (1997): 169-86; S. O'Sullivan, Early Medieval Glosses of Prudentius' Psychomachia: The Weitz Tradition. Mittellateinische Studien und Texte 31 (Leiden, 2004); and R. G. Babcock, The Psychomachia Codex from St. Lawrence (Bruxellensis 10066-77) and the Schools of Liège in the Tenth and Eleventh Centuries (Turnhout, 2017). 
this immensely popular poetic account of the battle of the virtues and the vices, Prudentius only rarely uses terminology associated specifically with cities. In his preface, he mentions the urbes of Sodom and Gomorrah, as well as the holy city of Jerusalem. ${ }^{30}$ However, as the pitched battle between the virtues and the vices comes to a conclusion, the virtue Concordia commands her army to divide into two long columns: "the infantry, in one column, intoned psalms; while on the other side the cavalry sang out hymns." 31 The other virtues follow her lead: "when they had conquered the swarm of the vices, the virtues in their sweet measured psalms echoed their sacred songs." 32 Prudentius then describes these melodious soldiers as entering the narrow passages of the gate of the fortification (ad fauces portae castrensis). ${ }^{33}$ Significantly, several early medieval manuscripts labeled their ornate illuminations of this joyous event "the virtues enter the city" (virtutes urbem ingrediuntur). ${ }^{34}$ Multiple ninth- and tenth-century manuscripts likewise glossed this castrum as urbs, suggesting some interchangeability in these civic terms. ${ }^{35}$

Prudentius himself draws out the close connections between the fortified mental city and physical civic sites. After Concordia was injured as she entered through the porta castrensis, the virtue Fides convinces the assembled virtues to follow Solomon's example by building a templum within their castrum. ${ }^{36}$ Fides then rhetorically asks, "For what does it profit to have driven back with the sword the earthly phalanx of vices, if the Son of Man coming down from high heaven and entering the city of the cleansed body (purgati corporis urbem) finds it unadorned and lacking a shining temple?"37 The crux of Fides's speech correlates Solomon's temple within Jerusalem with an embodied urbs symbolizing

30 For instance, Psychomachia, preface, 1.16-17: "Loth inmorantem criminosis urbibus / Sodomae et Gomorrae, quas fouebat aduena," ed. Cunningham, 149.

31 Psychomachia 1.648-49: “duceret ordinibus peditum psallente caterua, / ast alia de parte equitum resonantibus hymnis," ed. Cunningham, 172; trans. Thomson, 325, with emendations.

32 Psychomachia 1.663-64: "Sic expugnata uitiorum gente resultant / mystica dulcimodis uirtutum carmina psalmis," ed. Cunningham, 173; trans. Thomson, 325, with emendations.

33 Psychomachia 1.665, ed. Cunningham, 173.

34 See, for instance, Paris, Bibliothèque nationale de France, MS lat. 8085, fol. 66v (s.ix $\left.{ }^{3 / 4}\right)$; Paris, Bibliothèque nationale de France, MS lat. 8318, fol. 62v (s.ix); London, British Library, MS Cotton Cleopatra C VIII, fol. $31 \mathrm{v}\left(\mathrm{s} . \mathrm{x}^{4 / 4}\right)$, which also contains an Anglo-Saxon translation of this illumination's label; and Valenciennes, Bibliothèque municipale, MS 412 (393 bis), fol. 33 r (s.x/xi).

35 The gloss for 1.665 (ventum erat ad fauces portae castrensis ubi artum) in the Weitz W glosses is: uirtutes urbem ingrediuntur. See O'Sullivan, Early Medieval Glosses on Prudentius' Psychomachia (n. 29 above), 301.

36 Psychomachia 1.805-15, ed. Cunningham, 178.

37 Psychomachia 1.816-19: "Nam quid terrigenas ferro pepulisse falangas / culparum prodest, hominis si filius arce / aetheris inlapsus purgati corporis urbem / intret inornatam templi splendentis egenus?," ed. Cunningham, 178; trans. Thomson, 337, with emendation. 
the individual human being's readiness for the Second Coming. Whether figured as arx, castrum, or urbs, this civic terminology rhetorically asks its audience to envision themselves as a fortified city, guarded against vice and girded with virtus.

The fortified city required strong impregnable walls. In early medieval panegyrics, secular and ecclesiastical leaders at times became these very physical defenses of the city and its citizens. The Merovingian poet Venantius Fortunatus fused the physical defense of the city and the virtuous protection provided by its leader in an epideictic poem in praise of Bishop Vilicus of Metz (d. 568). Amongst praise for the happily situated city and the many merits of its bishop, Venantius apostrophizes the city of Metz, declaiming "O city, exceedingly well fortified, girt with wall (murus) and river, / you stand to flourish all the more through the merit of your bishop." 38 Venantius then turns to address Vilicus directly, casting the bishop himself as those walls, for "however much the wicked threatens with his vain blows, / they for whom you are a wall fear no hurt." 39

Carolingian authors likewise employed this metaphor of the ideal episcopal leader as civic structure and extended it to secular leaders as well. Abbot Alcuin of Tours wrote to Archbishop Ethelheard of Canterbury admonishing him to "be a shepherd, not a mercenary; a ruler, not an insurgent; light and not darkness, a city walled with firm faith (civitas firma fide murata), not a house destroyed by rains." 40 The Carolingian bishop Theodulf of Orléans (d. 821) crafted an epitaph for the recently deceased Pope Hadrian in which a personified Rome and her people - including "people of both sexes, the old, the young, the boy, the stranger (advena), and the citizen (civis)" — were called to "remember always this bishop [Hadrian] / who was the guardian of your riches, [who was] your arms and your wall." 41 Theodulf employs this same phrase - murus et arma - in the preface to his Libellus de processione spiritus sancti, in which Theodulf characterizes this "little book" as travelling to the Carolingian court and addressing Emperor

38 Venantius Fortunatus, Ad Vilicum episcopum Mettensem 1.15-16: "urbs munita nimis, quam cingit murus et amnis, / pontificis merito stas valitura magis," ed. F. Leo, MGH, Auctores antiquissimi 4.1 (Berlin, 1881), 66; trans. J. George, Venantius Fortunatus: Personal and Political Poems (Liverpool, 1995), 1. For further exploration of this poem and Venantius Fortunatus's oeuvre in general, see M. Roberts, The Humblest Sparrow: The Poetry of Venantius Fortunatus (Ann Arbor, 2009), 82-85. See also C. Saucier, A Paradise of Priests: Singing the Civic and Episcopal Hagiography of Medieval Liège (Rochester, 2014), 24-25.

39 Venantius Fortunatus, Ad Vilicum 1.23-24: "ictibus invalidis quamvis minitetur iniquus, / tu quibus es murus, vulnera nulla timent," ed. Leo, 66; trans. George, 2.

40 Alcuin, Epistola 17: "Esto pastor, non mercenarius; rector, non subversor; lux et non tenebrae; civitas firma fide murata, non domus pluviis diruta," ed. E. Dümmler, MGH, Epistolae 4 (Berlin, 1895), 45. For translation and context, see A. Firey, A Contrite Heart: Prosecution and Redemption in the Carolingian Empire (Leiden, 2009), 206-207.

41 Theodulf, Carmen 26, 1.25 and 1.27-28: "Sexus uterque, senex, iuvenis, puer, advena, civis . . Praesulis istius semper, tu Roma, memento, / Qui tibi tutor opum, murus et arma fuit," ed. E. Dümmler, MGH, Poetae 1 (Berlin, 1881), 490. 
Charlemagne itself. In the dialogue between the book and the emperor, the Libellus praises Charlemagne (who was still living) as the "decus of the world, the light of the kingdom, the defender of equality, as well as the murus et arma of the Catholic faith." ${ }^{42}$ Most poignantly, there is an epitaph composed by Bishop David II of Benevento (d. 796) for Romoald, who died soon after a series of failed negotiations on behalf of his father, Duke Arichis of Benevento, with Charlemagne. ${ }^{43}$ In this epitaph, supposedly engraved on the young heir's grave, David hailed Romoald as "the most beautiful of the great Arichis's children / The one hope of their patria, its walls and arms." 44

Although ideally enclosed and separated from the external world, early medieval texts on the monastic life at times employed civic discourse to illuminate how these largely non-urban communities should live. ${ }^{45}$ Hendrik Dey, for instance, has argued that walls played a central role in the formation of monastic identity in his examination of monastic rules from the fifth and sixth centuries. ${ }^{46}$ Although the number of instances of murus and related terms are limited, Dey finds that "conceptual walls" — that is, figural walls that separate the monks from the outside world - permeate these monastic rules. ${ }^{47}$ He draws attention to passages in the anonymous sixth-century work known as the Regula magistri, in which the body (and, indeed, the mind) of the monk is compared to a fortified enclosure. ${ }^{48}$ In one such passage, the Regula magistri conjures a metaphor

42 Theodulf, Carmen 36, 1.21-22: "Qui decus es mundi, lux regni, tutor et aequi, / Catholicae et fidei murus et arma simul," ed. Dümmler, 528. For the wider context of Theodulf's letters and poetry, see E. Rouquette, "Les lettres en vers de Théodulf d'Orléans," in Epistola: Écriture et genre épistolaires 1, ed. T. Deswarte, K. Herbers, and H. Sirantoine (Madrid, 2018), $259-71$.

43 For the wider context and translation, see J. M. Anderson, "Historical Memory, Authority, and the Written Word: A Study of the Documentary and Literary Culture at the Early Medieval Court of Benevento, 700-900 CE" (Ph.D. diss., University of Toronto, 2017).

44 Tituli saeculi VIII 1.3-4: "Hic Arichis dormit magni pulcherrima proles, / Unica spes patriae, murus et arma suis," ed. E. Dümmler, MGH, Poetae 1 (Berlin, 1881), 111. See also Duke Ursus of Benevento's (d. 915) epitaph, which labels the deceased duke as: "Ac simul in populo murus et arma suo. / Hic aemulos omnes superabat viribus, armis / Defendens patriam, promptus amore dei. / Hic honor atque suis requies portusque salutis. / Hic laus excelsa, hic generalis amor. / Iustitia clarus, renitens virtutibus almis." See Carmina varia 14 (Epitaphium Ursi), 1.10-15, ed. E. Dümmler, MGH, Poetae 2 (Berlin, 1884), 660.

45 See also the recent work of Claudia Rapp, who uncovers what she terms "citizenship language" among late antique Greek Christian authors in monastic settings: C. Rapp, "Monastic Jargon and Citizenship Language in Late Antiquity," Al-Masāq 32 (2020): 54-63.

46 H. Dey, "Building Worlds Apart: Walls and the Construction of Communal Monasticism from Augustine through Benedict," Antiquité Tardive 12 (2004): 357-71. I would like to thank an anonymous reviewer, who suggested this remarkably insightful article.

47 Dey, "Building Worlds Apart," 365.

48 Dey, "Building Worlds Apart," 365. 
comparing evil thoughts consuming the mind to a palace filled with mire and ineffective fortifications:

It is inappropriate that a palace should be cleansed on the outside while the room within is soiled with filth. Instead, the correct thing to do is to throw out the filth from inside, and only then the outside to be cleansed. Indeed, entrenchments (fossata) cannot be secure when the enemy is within. So also a bolted door is its own captor when the walls (muri) do not keep the enemy out, but hold him enclosed. ${ }^{49}$

The monk's mind as a fortified space finds further expression through the lens of civic discourse centuries later in Carolingian collections and commentaries on monastic life. In his Expositio regulae, Hildemar of Corbie and Civate compares those fighting alongside their fellow soldiers within a city to those monks who fought against the devil within the monastery. ${ }^{50}$ The comparison of a fortified city and a monastery is even more direct in the chapter on the character of the prior of the monastery. Hildemar recalls that Benedict of Nursia was greatly concerned with potential discord arising in the monastery, to the point that this represented "such a great evil that all good can be destroyed by the evil of discord."51 The Expositio then goes on to state that the corpus monasterii must be united against this malum discordiae, otherwise "it would not be able to stand against the enemy; because if a city or army fighting against an enemy were divided, it would not prevail, but [instead] would be given into the hands of its enemies by those whom it considers the opposition." 52

The cardinal civic term civitas could at times be applied to non-urban spaces and communities, as the seventh-century Antiphonary of Bangor attests. ${ }^{53}$

49 Regula Magistri 15: "Nec enim dignum est, mundatis foris regiis, cubiculum intus inquinari de sordibus, sed decenter efficitur, si de intrinsecus foris eiecta sorditie, iam tum demum et foras iuste mundetur. Non enim secura possunt esse fossata, ubi intus est hostis. Simul et porta clusura sua captiua est, ubi muri non repellunt, sed inclusum continent inimicum," in La Règle du Maître, ed. A. de Vogüé, SC 106 (Paris, 1965), 2:62-64. For the translation, see B. A. Saltzman, Bonds of Secrecy: Law, Spirituality, and the Literature of Concealment in Early Medieval England (Philadelphia, 2019), 268, n. 24.

50 Hildemar, Expositio regulae 1, in Expositio Regulae ab Hildemaro tradita, ed. R. Mittermüller (Regensburg, 1880), 77-78. This edition has been reviewed and corrected with a side-by-side English translation by the Hildemar Project: www.hildemar.org (accessed 24 June 2020). For the complicated manuscript transmission and context of this text, see M. de Jong, In Samuel's Image: Child Oblation in the Early Medieval West (Leiden, 1995), 70, n. 57; and S. Hamilton, The Practice of Penance, 900-1050 (Woodbridge, 2001), 84-89 and n. 45 .

51 Hildemar, Expositio regulae 65: "magnum malum, ut omne bonum pro discordiae malo posse deperire," ed. Mittermüller, 599.

52 Hildemar, Expositio regulae 65: "adversus hostem non possit consistere, quia si civitas vel exercitus pugnans adversus hostem divisa vel divisus fuerit, non poterit vincere, sed per eos, quos partis adversariae habet, in manus inimicorum suorum tradetur," ed. Mittermüller, 599.

53 Milan, Biblioteca Ambrosiana, MS Ambros. C. 5. inf, fol. 36r (s.vii). 
Written sometime between 680 and 691 , this antiphonary contains a hymn labeled in rubricated letters as Versiculi familiae Benchuir. After describing the rule and community of Bangor as full of virtue and happiness, the hymn offers a series of metaphors for the monastery itself, casting it as a sturdy ship, an expectant bride, a house built on a rock, and "the true vine / Transferred from Egypt." It proceeds to describe Bangor as "Surely a firm city, / Strong and united, / Glorious and worthy, / Situated on a mountain," and, a verse later, as a "queen for Christ / Clothed in the light of the sun / Simple, yet learned, / Unconquered on all sides." 55 While not fully drawn out in this short hymn, these verselets' association between a physical civitas and an unconquered regina could be read as suggesting a reinterpretation of the classical personified city. ${ }^{56}$ In this case, the author defined Bangor equally as a city on a mountain, a queen, and a community girded by a series of virtues. ${ }^{57}$

As these varied texts and contexts indicate, civic discourse penetrated to the core of late antique and early medieval thinking about how individuals and communities should structure their actions. It provided a framework for mental fortification, a vocabulary for praising exemplary individuals, and a flexible iconography which could be adapted even to non-urban places like monasteries. The primary link between each of these uses of civic terminology consists in the need for one's civitas to be guarded, to be defended, and to be peopled with virtue.

\section{Civic Personification and Public Processions in Late Antique and Early Medieval Cities}

Human beings, as we have seen, can be described as cities. Cities, in their turn, could be figured as human beings. In their discussions of cities past and present, classical and medieval authors frequently employed the rhetorical technique of personification, or prosopopoeia. ${ }^{58}$ Deeply rooted in rhetorical tradition,

54 Versiculi familiae Benchuir I.15-16: "Necnon vinea vera / Ex Aegypto transducta." ed. F. E. Warren, in The Antiphonary of Bangor (London, 1893-95), 2:28; trans. P. O'Dwyer, Mary: A History of Devotion in Ireland (Dublin, 1988), 35-36.

55 Versiculi familiae Benchuir I.17-20 and I.27-30: "Certa civitas firma, / Fortis atque unita, / Gloriosa ac digna, / Supra montem posita . . Christo regina apta, / Solis luce amicta, / Simplex simulque docta, / Undecumque invicta," ed. Warren, 2:28; trans. O'Dwyer, 35-36.

56 See below for an extended analysis of the personified city.

57 Bangor as a city on a mountain has obvious scriptural overtones, particularly from Psalm 47:2 (in ciuitate Dei nostri in monte sancto eius), which also was referenced by other early medieval Irish authors, including the late seventh-century De locis sanctis by Adomnán. See T. O’Loughlin, "Perceiving Palestine in Early Christian Ireland: Martyrium, Exegetical Key, Relic and Liturgical Space," Ériu 54 (2004): 125-37.

58 M. W. Bloomfield, "A Grammatical Approach to Personification Allegory," Modern Philology 60 (1963): 161-71; E. H. Gombrich, "Personification," in Classical Influences in 
personification "operates in multiple registers - sensory and spiritual, visible and invisible, concrete and abstract — and it deals in facts, opinions and beliefs." 59 Exercising impressive powers of imagination, authors across this period cast cities in specific human forms, cloaked them with carefully considered attributes, and placed eloquent speeches into their mouths. ${ }^{60}$

One distinctive feature of the technique of personification is that it can be employed equally in texts and images. Scholars such as Gudrun Bühl and Alan Cameron have drawn attention to the complex ways in which the personified cities of Rome and Constantinople figured in a variety of media throughout Late Antiquity. ${ }^{61}$ The image of the personified Roma often stands behind newly elected consuls in consular diptychs of the fifth and sixth centuries, while in one particularly intriguing set, the personified cities of Rome and Constantinople each take up an entire frame of ivory. ${ }^{62}$ Other leading cities of the late Empire were also personified. Londinium, for instance, appears on a gold medallion minted in the wake of Constantius Chlorus's reconquest of Britain in $296 \mathrm{CE}$; kneeling, she raises her hands in supplication in front of the turreted gates of the city wall. ${ }^{63}$ Personified cities also populate the folios of deluxe early medieval copies of late antique manuscripts. The intricate compilation of late antique pagan and Christian texts and images known variously as the Codex-Calendar of 354, the Chronograph of 354, or the Calendar of Philocalus, for instance, contains four full-page illustrations of the city tyches of Rome, Alexandria, Constantinople, and Trier. ${ }^{64}$

European Culture AD 500-1500, ed. R. R. Bolger (Cambridge, 1971), 247-57; J. Paxson, The Poetics of Personification (Cambridge, 1994); and Personification: Embodying Meaning and Emotion, ed. W. Melion and B. Ramakers (Leiden, 2016).

59 W. Melion and B. Ramakers, "Personification: An Introduction," in Personification, 1.

60 Isidore, for instance, defines prosopopoeia thus: "Prosopopoeia occurs when personality and speech are invented for inanimate things . . . Thus we bring in speaking mountains and rivers or trees, imposing personhood on a thing that does not have the capacity for speech." Isidore, Etymologiae 2.13.1-2 (n. 20 above), ed. Lindsay, 103; trans. Barney et al. (n. 20 above), 74 .

61 G. Bühl, Constantinopolis und Roma: Stadtpersonifikationen der Spätantike (Zürich, 1995); and A. Cameron, "City Personifications and Consular Diptychs," Journal of Roman Studies 105 (2015): 250-87. See also M. Roberts, "Rome Personified, Rome Epitomized: Representations of Rome in the Poetry of the Early Fifth Century," The American Journal of Philology 122 (2001): 533-65.

62 Vienna, Kunsthistorisches Museum, Antikensammlung, X 37 and X 38.

63 London, British Museum, B.11477 (found in Beaurains, near Arras, in 1992).

64 For detailed analyses of the contents, transmission, and influence of this complex manuscript, see T. Mommsen, "Über den Chronographen vom J. 354," Abhandlungen der Philologisch-Historischen Klasse der Königlich-Sächsischen Gesellschaft der Wissenschaften 1 (1850): 547-693; M. Schapiro, "The Carolingian Copy of the Calendar of 354," Art Bulletin 22 (1940): 270-72; H. Stern, Le calendrier de 354: Étude sur son texte et ses illustrations (Paris, 1953); G. Binder, Der Kalender des Filocalus oder der Chronograph vom Jahre 354 (Meisenheim, 1970); M. R. Salzman, On Roman Time: The Codex-Calendar of 354 and the Rhythms 
Each personified city sits or stands draped in chitons and embellished with distinctive insignia, as Rome sits clad in armor and Constantinople stands adorned with a mural crown. ${ }^{65}$ These illuminations of personified cities, along with the personifications transmitted through other manuscripts such as the Notitia Dignitatum, had a demonstrable impact on Carolingian and Ottonian illuminated manuscripts. ${ }^{66}$

Shifting from image to text, the personified city also figures prominently in the works of several late antique authors, including the fourth-century poets Claudian (d. 404) and his contemporary Prudentius, already mentioned above. In 404, Claudian stood before the assembled crowds of Rome to praise their approaching emperor, Honorius, in a threefold celebration of the emperor's triumph over the Goths, his slightly belated decennalia, and his sixth consulship. ${ }^{67}$ Claudian cast a lengthy section of his panegyric as a dialogue between the young emperor and a personified Rome - who, unable to bear any longer the delay of "what the City with one voice was praying for," - convinces the young ruler to return. ${ }^{68}$ After recounting the emperor's journey from Ravenna, Claudian describes the recently rebuilt Aurelian walls as the source of Rome's defense and renewal. ${ }^{69}$ Immediately after this description, Claudian shifts focus to Rome's citizens. "All the space," Claudian declaims, "that extends from the Palatine hill as far as the Milvian Bridge, and from the ground up as far as the roofs could soar, was filled by a crowd that wore a single face: you could see the ground flooded with waves of men and the high buildings ablaze with matrons."70 Together

of Urban Life in Late Antiquity (Berkeley, 1991); and R. W. Burgess, "The Chronograph of 354: Its Manuscripts, Contents, and History," Journal of Late Antiquity 5.2 (2012): 345-96.

65 Vatican City, Biblioteca Apostolica Vaticana, MS Barb. lat. 2154b, fols. 2r-5r; and Vatican, Biblioteca Apostolica Vaticana, MS Vat. lat. 9135, pp. 281-85.

66 The full extent of this influence is much debated and the scholarship on Carolingian and Ottonian Herrscherbilder is extensive. For discussions of personification in these images, see W. Weizsäcker, "Imperator und huldigende Frauen," in Festschrift für Karl Gottfried Hugelmann zum 80. Geburtstag am 26. September 1959 dargebracht von Freunden, Kollegen und Schülern, ed. K. Hugelmann and W. Wegener (Aalan, 1959), 2:815-31; K. Hoffmann, “Das Herrscherbild im 'Evangeliar Ottos III.' (clm 4453)," Frühmittelalterliche Studien 7 (1973): 324-41; and F. Mütherich, "Das Kaiserbild," in Das Evangeliar Ottos III: Clm 4453 Bayerische Staatsbibliothek München, ed. eadem and K. Dachs (Munich, 2001), 31-55.

67 A. Cameron, Claudian: Poetry and Propaganda at the Court of Honorius (Oxford, 1970), 180-81; S. MacCormack, Art and Ceremony in Late Antiquity (Berkeley, 1981); and M. McEvoy, Child Emperor Rule in the Late Roman West, AD 367-455 (Oxford, 2013), 172-74.

68 Claudian, Panegyricus de sexto consulatu Honorii Augusti 1.357-58: "donec differri longius urbis / communes non passa preces," ed. and trans. M. Dewar, in Claudian: Paneyricus de sexto consulatu Honorii Augusti (Oxford, 1996), 24-25.

69 Claudian, Panegyricus 1.531-36, ed. and trans. Dewar, 36.

70 Claudian, Panegyricus 1.543-46: “omne Palatino quod pons a colle recedit / Muluius et quantum licuit consurgere tectis, / una replet turbae facies: undare uideres / iam uiris, altas effulgere matribus aedes," ed. and trans. Dewar, 36-37. 
this mixed and massive assembly praised the emperor and judged that Honorius had come before them as a fellow citizen (civem). ${ }^{71}$ In this panegyric intended for public performance, Claudian places the citizens directly on the fabric of the physical city, enlivening the streets and illuminating the buildings. In doing so, the poet blurs the boundary between the city as physical site and as rhetorical conceit. ${ }^{72}$

Claudian's contemporary Prudentius likewise brings cities to life through the technique of personification. ${ }^{73}$ Quite apart from the Psychomachia, his Liber Peristephanon, a collection of fourteen poems composed in a wide variety of meters and set as hymns, charts how various saints abide in and guide the civitates in which they were martyred and where their tombs reside. ${ }^{74}$ In his eloquent study of Prudentius, Cillian O'Hogan rightly argues that the poet centers the martyr of each hymn as the heart of their respective cities. However, while O'Hogan suggests that "the city itself fades into the background," this effacement does not include the civic community, or the citizens' connection to their civic space. ${ }^{75}$

For Prudentius, a martyr can transform the physical city and its citizens alike. In his metrical hymn for Bishop Fructuosus and deacons Augurius and Eulogius of Tarragona, for example, Prudentius addresses their personified city as felix Tarraco, whose head (caput) is aflame with the fire of her three martyrs and whose happiness stems from God's favor "for it is the mighty Trinity that crowns / With triple martyrs this Iberian city (arcem)." 76 This personification recurs at the hymn's conclusion, when Prudentius proclaims "Oh, how our

71 Claudian, Panegyricus 1.558-59: “idque inter ueteris speciem praesentis et aulae / iudicat, hunc ciuem, dominos uenisse priores," ed. and trans. Dewar, 38-39.

72 Dated to 401 or 402, three inscriptions record the erection of statues to the emperors Honorius and Arcadius, which were placed at three restored gates on Aurelian's third-century wall. These were the Portae Praenestina-Labicana, Tiburtina, and Portuensis. Each inscription declared that the senatus populusque Romanus set up these statues "because of the restoration of the walls, gates, and towers of the Eternal city, with the removal of immense ruins." See Corpus Inscriptionum Latinarum VI: Inscriptiones urbis Romae latinae pars prima, ed. E. Bormann and G. Henzen (Berlin, 1876), 248 (nos. 1188, 1189, and 1190).

73 Prudentius employed the personification of cities in other works as well, most famously in the second book of his Contra Symmachum. In this remarkable poem, Prudentius transforms the aged Rome as depicted by Symmachus into a young, peaceful civitas rejuvenated under her Christian emperors. See, for example, Roberts, "Rome Personified, Rome Epitomized" (n. 61 above), 538-39.

74 P. Hershkowitz, Prudentius, Spain and Late Antique Christianity: Poetry, Visual Culture, and the Cult of Martyrs (Cambridge, 2017); and M. Mastrangelo, The Roman Self in Late Antiquity: Prudentius and the Poetics of the Soul (Baltimore, 2008).

75 O'Hogan, Prudentius and the Landscapes of Late Antiquity (n. 29 above), 94.

76 Peristephanon 6, 1.1-6: "Felix Tarraco, Fructuose, vestris, / attollit caput ignibus coruscum / leuuitis geminis procul relucens. / Hispanos deus aspicit benignus, / arcem quandoquidem potens Hiberam / trino martyre trinitas coronat," ed. Cunningham, 314; trans. Krisak, 89, with slight emendations. 
city's head is exalted! Triple / Honor, triple glory we obtain / In towering over all the cities of Spain!"77 He then entreats "choirs of both sexes [to] stand and sing / Grown men, maidens, boys, girls, and the old" all together to chant hymns in praise of their martyrs. ${ }^{78}$ Prudentius then links this civic choir's hymns to the physical city itself, entreating the singers to redouble their voices so that the gilded roofs of the city (arx) will resound. ${ }^{79}$

Prudentius restates this intricate connection between citizens, martyrs, and the personified city in his hymn for the eighteen martyrs of Caesaraugusta (modernday Zaragoza). Unlike many other hymns in the Peristephanon, these verses do not narrate their subjects' martyrdom. Instead, Prudentius envisions a Judgment Day "when God, upon on a cloud of flame, / Shaking His flashing hand, shall come / To set His scale, to bless or blame, / Weighing all justly." 80 When this occurs, according to Prudentius, individual cities will raise their heads and rush to meet Christ, bearing their martyrs along in baskets. ${ }^{81}$ Carthage bears the bones of Cyprian, Tarragona proffers "a diadem / Fructuosus wove with triple gems," while Alcala delights in bearing the blood of Justus forward.$^{82}$ After narrating this parade of personified cities bearing relics of their saints, Prudentius then declares that Caesaraugusta will step forward, outshining each of the other cities with her eighteen martyrs and a head wreathed with golden olives. ${ }^{83}$ Because she bears so many martyrs, Prudentius claims that Caesaraugusta stood alone as "richer than all who have adored Him." ${ }^{84}$ Crucially, Prudentius concludes this hymn by addressing the sancta civitas of Caesaraugusta, entreating the city to "prostrate yourself, with me, great city, / Upon these holy graves" in order to ensure that Caesaraugusta and its citizens will indeed be resurrected. ${ }^{85}$

77 Peristephanon 6, 1.142-44: "O triplex honor, o triforme culmen, / quo nostrae caput excitatur urbis, / cunctis urbibus eminens Hiberis!" ed. Cunningham, 319; trans. Krisak, 93, with slight emendations.

78 Peristephanon 6, 1.148-49: “Circumstet chorus ex utroque sexu, / heros virgo puer senex anulla," ed. Cunningham, 319; trans. Krisak, 93.

79 Peristephanon 6, 1.154: "Hinc aurata sonent in arce tecta," ed. Cunningham, 319.

80 Peristephanon 4, 1.9-12: "Cum Deus dextram quatiens coruscam / nube subnixus veniet rubente / gentibus iustam positurus aequo / pondere libram," ed. Cunningham, 286; trans. Krisak, 62.

81 Peristephanon 4, 1.14-16: "obuiam Christo properanter ibit / ciuitas quaeque pretiosa portans / dona canistris," ed. Cunningham, 286.

82 Peristephanon 4, 1.21: "tribus gemmis diadema pulchrum," ed. Cunningham, 286; trans. Krisak, 62.

83 Peristephanon 4, 1.55-56: "uerticem flauis oleis reuincta," ed. Cunningham, 288.

84 Peristephanon 4, 1.59: "sola praediues pietate multa," ed. Cunningham, 288; trans. Krisak, 60.

85 Peristephanon 4, 1.197-98: "Sterne te totam generosa sanctis / ciuitas mecum tumulis," ed. Cunningham, 293; trans. Krisak, 68. 
Throughout his hymns, Prudentius emphasizes the power of the personified city and its citizens, whose voices echoed throughout the physical city.

Prudentius's hymnal retrospective on the Christian transformation of civitates in the Roman world resonated far beyond fifth-century Iberia. ${ }^{86}$ The widespread reception of Prudentius's work throughout western Christendom in the early Middle Ages has attracted the attention of several scholars, who have carefully analyzed the extensive glossing traditions, the magnificent illumination cycles (particularly of his Psychomachia), and the incorporation of Prudentian phrases into new works. ${ }^{87}$ The Peristephanon has been identified as a model for one of the most famous authors of the tenth century, the Ottonian canoness Hrotsvitha of Gandersheim. ${ }^{88}$ As a Christian response to Terence's plays, Hrotsvitha created eight sacred stories in poetic form for the delight of an educated audience, at times peppering her plays with Prudentian phrases. ${ }^{89}$

Hrotsvitha framed one of these stories, the tenth-century martyrdom of a young Leonese Christian, Pelagius, within a decidedly civic context, beginning with the personified city of Córdoba. ${ }^{90}$ After an initial prayer from Hrotsvitha

86 Early medieval scribes copiously copied the Liber Peristephanon in the eighth, ninth, and tenth centuries, often accompanying these hymns with their own interlinear glosses and marginalia. In several copies of Prudentius's hymn for the eighteen martyrs of Caesaraugusta, for instance, early medieval scribes identified each of the personified cities with the gloss of civitas, ostensibly for identification of these foreign place names. See, for instance, Bern, Bürgerbibliothek, MS Cod. 264, p. 105. A digitized facsimile can be found here: https:/ www.e-codices.unifr.ch/en/bbb/0264/105/0/Sequence-33 (accessed 24 July 2020).

87 See n. 29 above.

88 W. Berschin, "Tradition und Neubeginn bei Hrotsvit von Gandersheim (+ nach 968)," in idem, Mittellateinische Studien (Heidelberg, 2005), 237-48, at 243; and S. L. Wailes, "The Sacred Stories in Verse," in A Companion to Hrotsvit of Gandersheim (fl. 960): Contextual and Interpretive Approaches, ed. P. R. Brown and S. L. Wailes (Leiden, 2012), 83-120, at 91-95.

89 For examples, see O'Sullivan, Early Medieval Glosses (n. 29 above), 17; and Hrotsvithae Opera, ed. P. von Winterfeld, MGH, Scriptores rerum germanicum 34 (Berlin, 1902), 52, n. 13. Perhaps Hrotsvitha also had Prudentius's description of Tarragona as a genetrix piorum (Peristephanon 4.27) in mind when she labelled Córdoba as a purae fidei genetricem (1.37).

90 Passio Pelagii, 63-78. Two other tenth-century texts were devoted to the martyrdom of Pelagius: one earlier vita by the Cordoban priest Raguel before 967 and a liturgical rite dated soon after the saint's translation in 967 to San Salvador abbey in León. The scholarship on the martyrdom of Pelagius in general, and Hrotsvitha's metrical vita in particular, is extensive, particularly in the fields of early medieval Muslim-Christian relations and queer studies. See, for instance, C. Rodriguez Fernandez, La pasiòn di S. Pelayo (Santiago de Compostela, 1991); A. R. Christys, Christians in Al-Andalus 711-900 (Abingdon, 2002), 94-101; J. V. Tolan, Saracens: Islam in the Medieval European Imagination (New York, 2002), 106108; L. Weston, "The Saracen and the Martyr: Embracing the Foreign in Hrotsvit's Pelagius," in Meeting the Foreign in the Middle Ages, ed. A. Classen (New York, 2002), 1-10; and J. A. Bowman, "Beauty and Passion in Tenth-Century Córdoba," in The Boswell Thesis: Essays on Christianity, Social Tolerance, and Homosexuality, ed. M. S. Kuefler (Chicago, 2006), 236-53. 
herself to the young martyr in heaven, the poem begins by describing the city of Córdoba as an urbs augusta, illustrious and renowned, but with the very human failing of superba due to her new fierceness in war. ${ }^{91}$ Once a city filled with Christian cives ruled by a virtuous Christian king, the city now suffers under the yoke of a perfidia gens led by a perverse and profane man. ${ }^{92}$ As a result, the lamenting city (maerentem urbem) was filled with many barbarous enemies, who "defiled the ancient mother of pure faith" by attempting to persuade the rightful inhabitants (iusti coloni) to discard their patrios mores. ${ }^{93}$

Over the course of this poetic passio, Pelagius suffers the life of a hostage and the unwanted advances of the caliph, which resulted in the caliph ordering the young Christian to be catapulted from the walls of Córdoba onto the rocky banks of the river below, and eventually his decapitation. After his remains were found by fishermen, Pelagius's remains were brought secretly to an unnamed monastery consecrated within the city's walls (urbis muros) where a Christian throng soon gathered to receive the relics of their recent martyr while singing hymns. ${ }^{94}$ According to Hrotsvitha, the caliph had tried to eject Pelagius from the city, hurling him over the city walls and, consequently away from Córdoba's cives; however, Pelagius triumphed not only by gaining his martyr's crown, but also by returning to the very heart of the Christian community, with the city once more reverberating with the voices of its Christian citizens.

In each of these authors, the personified city was accompanied by the songs, hymns, and resonating voices of its citizens. Personification permitted poets to put words into the mouths of cities, while public processions provided an opportunity to air the voice of the entire body of citizens. ${ }^{95}$ Gregory of Tours, for instance, provides a record of Visigothic citizens coming together to defend their city through processions in the sixth century. ${ }^{96}$ According to Gregory, the

91 Passio Pelagii 1.13: "Urbs augusta nova Martis feritate superba," ed. Berschin, 63. For a recent metrical translation, see K. Wilson, "Hrotsvit of Gandersheim's Pelagius," in Medieval Women's Visionary Literature, ed. E. A. Petroff (Oxford, 1986), 114-23.

92 Passio Pelagii 1.19-20, 24, and 31-32, ed. Berschin, 63 and 64.

93 Passio Pelagii 1.37, 39-40: "purae fidei genetricem . . Paganos iustis intermiscendo colonis, / Quo sibi suaderent patrios dissolvere mores," ed. Berschin, 64.

94 Passio Pelagii 1.350-51 and 354: "Et clam coenobium Christo petiere sacratum / Intra non modicos urbis venerabile muros . . Quod gaudens hymnis suscepit turba fidelis," ed. Berschin, 75 .

95 The body of scholarship on early medieval liturgical processions and how they transformed civic space is extensive. See, for instance, J. Hill, "The litaniae maiores and minores in Rome, Francia and Anglo-Saxon England: Terminology, Texts, and Traditions," Early Medieval Europe 9 (2000): 211-46; and J. Latham, "The Making of Papal Rome: Gregory I and the letania septiformis," in The Power of Religion in Late Antiquity, ed. N. Lenski and A. Cain (Farnham, UK, 2009), 293-304.

96 For Prudentius's manuscripts and impact, see O'Hogan, Prudentius and the Landscapes of Late Antiquity (n. 29 above). 
Merovingian king Childebert I and his son Chlothar I led a campaign into the Iberian peninsula in 542. As the kings and their army besieged the city of Zaragoza, Gregory claims that the citizens

turned in great humility to God: they dressed themselves in hair-shirts, abstained from eating and drinking, and marched round the city walls singing psalms and carrying the tunic of Saint Vincent the martyr. Their women-folk followed them, weeping and wailing, dressed in black garments, with their hair blowing free and with ashes on their heads. ${ }^{97}$

Gregory states that the Merovingians had no idea what was happening around the walls of Zaragoza, for "as they watched them march round the walls they imagined that it was some curious kind of black magic."98 After they learned that the citizens were praying to St. Vincent for deliverance, the Merovingian army became afraid and "they withdrew from that city." 99

The mounting of civic processions in the face of danger would not have been unknown to Gregory of Tours. In his Liber in Gloria confessorum, Gregory narrates how, in the wake of news of a certain "plague of the groin" spreading throughout Germania, the people of Reims rushed to the tomb of St. Remigius where "they kept watch for the entire night while singing hymns and celestial psalms."100 The following morning, the citizens were divinely inspired to "fortify the

97 Gregory of Tours, Historiae 3.29: "in tanta humilitate ad Deum conversi sunt, ut induti ciliciis, abstinentis a cibis et poculis, cum tonica beati Vincenti martiris muros civitatis psallendo circuirent; mulieres quoque amictae nigris palleis, dissoluta caesariae, superposito cinere," ed. B. Krusch and W. Levison, MGH, Scriptores rerum Merovingiorum 1.1 (Hannover, 1951), 125; trans. L. Thorpe, Gregory of Tours: The History of the Franks (London, 1974), 186. See the description of these events in the vita of Abbot Droctovei, which similarly describes the citizens of Zaragoza circumambulating with the tunic of St. Vincent cum hymnodiis muros civitatis. See Gislemarus, Vita Droctovei abbatis Parisiensis 11, ed. B. Krusch, MGH, Scriptores rerum Merovingiorum 3 (Hannover, 1896), 540.

98 Gregory of Tours, Historiae 3.29: "cum viderent sic murum circuire, putabant, eos aliquid agere maleficii," ed. Krusch and Levison, 125-26; trans. Thorpe, 187.

99 Gregory of Tours, Historiae 3.29: "quod illi timentes, se ab ea civitate removerunt," ed. Krusch and Levison, 126; trans. Thorpe, 187. The eighth-century Liber Historiae Francorum supposedly adds further detail to Childebert's and Chlothar's encounter with Zaragoza, for the author states that Childebert negotiated a peace with the city's bishop in exchange for a relic of St. Vincent, which the king then transported back to Francia, and built the church of St-Germain-des-Prés as a house for this relic. See Liber Historiae Francorum A.26, ed. B. Krusch, MGH, Scriptores rerum Merovingiorum 2 (Hannover, 1888), 284. For the wider context and historical veracity of this episode, see N. Ristuccia, Christianization and Commonwealth in Early Medieval Europe: A Ritual Interpretation (Oxford, 2018), 151-53.

100 Gregory of Tours, Liber in gloria confessorum 78: "hymnis psalmisque caelestibus per totam excubat noctem," ed. B. Krusch, MGH, Scriptores rerum Merovingiorum 1.2 (Hannover, 1969), 346; trans. R. Van Dam, Gregory of Tours: Glory of the Confessors (Liverpool, 1988), 59. 
defense of the city (urbs) with a still more effective defense." 101 Gregory of Tours plays with the word propugnaculum here, a term that signified defense or a bulwark in a general sense, but one that was also closely tied to city walls. ${ }^{102}$ The additional layer - which, according to Gregory was the more effective layer - of defense for the city lay in the procession of its citizens and their supplications to St. Remigius. The citizens of Reims journeyed "around the city (circumeunt urbem) as well as [through] its villages" with St. Remigius's shroud. ${ }^{103}$ Thankfully, Gregory reports that as the plague approached the city's border (fines huius civitatis), the pestilence could not advance past the edge of the processional route. Gregory's portrayal of these liturgical responses to urban menaces points to the continued currency of a civic discourse in which the communal words and actions of the city, citizens, and saint could directly impact the survival of the city itself.

Collations of civic bodies concerned for the defense of their city also appear in Carolingian narratives of relic translations. In the poetic Sancti Cornelii Compendiensis translationes, the anonymous author claimed that the rejoicing people (gaudens plebs) of Compiègne swarmed around the arriving relics of St. Cornelius, stretching to touch the posts of the saint's bier as the relics were carried by King Charles the Bald and his bishops to their new resting place. ${ }^{104}$ As the turba multa clericorum proceeded, followed by the turba plebis, they sang together with a "great voice," and their singing "reverberated with a loud song of praise." 105 The verses later clarify who precisely made up these crowds, as the poet claims that "the old man and the old woman, together with the young men and the little ones / the holy cleric and all of the plebs cry out for you, having been enticed to you." 106 The verses culminate in a prayer specifying the relationship between the city, citizens, and their saint, as the poet calls upon

101 Gregory of Tours, Liber in gloria confessorum 78: "maiori propugnaculo urbs propugnacula munirentur," ed. Krusch and Levison, 346; trans. Van Dam, 59.

102 Although completed around a quarter of a century after Gregory's death, Isidore of Seville's Etymologiae proves illuminating: "Bulwarks (propugnaculum) are the pinnacles (penna) of city walls, so called because from them the city is 'fought for' (propugnare)." Isidore, Etymologiae, 15.2.20 (n. 20 above), 161; trans. Barney et al, Etymologies (n. 20 above), 306.

103 Gregory of Tours, Liber in gloria confessorum 78: "circumeunt urbem cum vicis," ed. Krusch and Levison, 346; trans. Van Dam, 59.

104 Sancti Cornelii Compendiensis translationes 1.7: "Plebsque supplex confluebat fulchra gaudens tangere," ed. P. von Winterfeld, MGH, Poetae 4.1 (Berlin, 1964), 237.

105 Sancti Cornelii Compendiensis translationes 1.8 and 1.10: "Antecedit turba multa clericorum candida, / Subsecuta est turba plebis ut viginti milia / Concinentes voce magna gratias altissimo . . . Hi canunt, illi resultant / clara laudum carmina," ed. von Winterfeld, 238.

106 Sancti Cornelii Compendiensis translationes 3.6: "Te senes anusque simul, iuvenes et parvuli, / Clerus sacer et plebs omnis invitando clamitant, / Caeci quoque atque claudi cum turba debilium," ed. von Winterfeld, 241. 
St. Cornelius to "fortify this city (civitatem istam) with your protection" and likewise to "protect its citizens (eius cives) with your intercession." 107

Whether echoing with the words of citizens in procession or speaking itself in personified form, the security of the late antique and early medieval city seemed to require the consistent articulation of its virtue. Saints, along with ecclesiastical and secular leaders, played primary roles in this articulation; yet the entire civic body was implicated. The repetition of such phrases as "girls and boys, old men and women" underscores the importance of these communal actions in the city, while prayers addressed to the city's saints and to God often require that the supplicants prove themselves worthy of intercession or deliverance.

\section{The City Celebrated and Condemned: Early Medieval Encomia, Invective, and Urban Fortifications}

The security of the early medieval city depended on the virtue of its citizens, their devotion to and care for their city's saints, and the diligent maintenance and guarding of the city's walls. The poetic genre known as laudes urbium provides insights into each of these ideals structuring early medieval urban life, notably in cities within the Italian peninsula, but also across the Alps. When analyzing laudes urbium, scholars tend to focus on how closely early medieval authors adhered to classical topoi and what the poetic descriptions embedded in each poem can and cannot tell us about "real" life in early medieval cities. ${ }^{108}$ More recently, however, scholars have revisited these poems from a different angle. Thomas Granier, for instance, recently reexamined the ninth-century polemical (or, as Granier would argue, elegiac) Versus Romae and its complex manuscript transmission, ultimately arguing that this twenty-four hexameter invective underscores its author's "commitment to the city in the sense of identity and belonging." 109 Likewise, in her analysis of the creation of liturgical hymns in Liège beginning ca. 1000 and spanning the next eight centuries, Catharine Saucier eloquently reexamines the earlier liégeois hymns from the tenth century in light of the laudes urbium tradition. Crucially, Saucier argues that "we can begin to consider as 'civic' a fuller spectrum of ideas, both secular and sacred, that reflect and celebrate the diversity characteristic of every civic community." 110 Whereas Saucier concentrates on civic identity embedded in central and later medieval liégeois hymns, Paul Oldfield examines what he terms "civic

107 Sancti Cornelii Compendiensis translationes 3.10 and 3.11: "Civitatem istam tuo muni patrocinio . . Eius quoque cives tuo interventu protege," ed. von Winterfeld, 241.

108 See n. 6 above.

109 Granier, "À rebours des laudes ciuitatem" (n. 6 above), 131.

110 Saucier, Paradise of Priests (n. 38 above), 9. 
consciousness" in urban panegyrics from the twelfth through the fourteenth century. Civic consciousness, according to Oldfield, was a specific "mode of being" that "created appreciation of the positive values connected with the urban world, attached pride to one's home city, and countered negative, disparaging perspectives on the city." 111 To uncover this civic consciousness, Oldfield analyzes urban panegyrics in the later Middle Ages, arguing that this genre "has often been dismissed as being too bound by convention, rhetoric, and exaggeration and therefore rather sidelined from the understandings of the medieval city." 112

Oldfield and Saucier concentrate on the clerical composition of, and audience for, medieval hymns, as well as the increased production of civic encomia in the central and later Middle Ages. Yet earlier medieval urban panegyrics often reflected strikingly similar constructions of civic identity, prescribing how citizens should act and contemplating how failures of virtue could lead to communal demise. Much of this discussion surrounding civic virtue related to the upkeep and defense of the city's walls. Walls, in these poems, not only physically defended the city, but also echoed the triumphs and tribulations of the cities themselves.

The well-known laus dedicated to Milan, and its later emulator, the Versus de Verona, each celebrate the personified city and its well-defended walls. ${ }^{113} \mathrm{Com}$ posed around 740, the Versum de Mediolano civitate praises Milan as the urbium regina mater adque patrie, a beautifully built and spacious city with carefully constructed towers, twelve-foot-wide stone walls, and nine gates secured with iron bolts and well-guarded drawbridges. ${ }^{114}$ Her populus, moreover, are characterized by their great charity, as they all hurry to church to proffer gifts before the

111 Oldfield, Urban Panegyric (n. 6 above), 2.

112 Oldfield, Urban Panegyric (n. 6 above), 3.

113 Versus de Verona. Versum de Mediolano civitate, ed. G. B. Pighi (Bologna, 1960), 14547 and 152-54; G. Fasoli, "La coscienza civica nelle 'Laudes Civitatum'," in La coscienza cittadina nei comuni italiani del Duecento, Atti dell'XI convegno del Centro di studi sulla spiritualità medievale (Toti, 1972), 11-44; J.-C. Picard, "Conscience urbaine et culte des saints: De Milan sous Liutprand à Vérone sous Pépin Ier d'Italie," in Hagiographie, cultures et sociétés (IVe-XIIe siècles): Actes du Colloque organisé à Nanterre et à Paris (2-5 mai 1979), ed. idem (Paris, 1981), 455-69; C. La Rocca, "Lo spazio urbano tra VI e VIII secolo," in Uomo e spazio nell'alto Medioevo, Settimane del CISAM 50 (Spoleto, 2003), 397-436, at 406-15; R. Avesani, "Il re Pipino, il vescovo Annone e il Versus de Verona," in I santi Fermo e Rustico: Un culto e una chiesa in Verona, ed. P. Golinelli and C. G. Brenzoni (Verona, 2004), 57-65; Trout, "Theodelinda's Rome" (n. 13 above), 143-44; and P. Majocchi, "L'esercito del re e le città: organizzazione militare degli eserciti urbani in Italia settentrionale (viii-xi sec.)," in Urban Identities in Northern Italy (n. 11 above), 103-149 at 118-125. Another set of laudatory verses often analyzed in the context of the following two poems are the veduta that surround the Iconografia Rateriana. While this remarkable early tenth-century depiction of Verona does depict the walls of the city, the Adige river (and not the city) is personified and the verses themselves do not touch upon civic defense or the walls as such.

114 VMC 1.7-15, ed. Pighi, 145-46. With the Versum de Mediolano civitate, I follow Pighi's title. 
altar. ${ }^{115}$ Milan's charitable citizens not only benefit from the city's wide walls, but also remain secure through the saints that rest joyfully around the walls. ${ }^{116}$ The Versum de Mediolano civitate then declares that as no other city could boast of so many blessed cadauera, Milan is a truly "happy and blessed city, which desires to have so many holy defenders, by whose prayers she remains unconquered and fertile." 117 After praising the pious king, Liudprand (d. 744), and Milan's bishop Theodore (d. 735), the author then honors the cives of Milan, who in their firm faith stand against nefandarum gentium, encouraging the cives to pray with him and to sing hymns together, "so that he [Christ] may deem this city worthy to be ruled and guarded, and free her from all evils." 118

The later eighth-century author of the Versus de Verona speaks to this personified city directly, declaring that "no city in Ausonia deserves more praise than you, / Splendid, powerful and fragrant from the bodies of saints, / among a hundred [cities] the most opulent in Italy." 119 These civic saints encircle Verona, embracing her and her citizens to make her "happy, enriched, distinguished, / and surrounded by a throng of most holy guardians (custodes sanctissimi), / to defend and drive the wicked enemy away from you." 120 According to the Versus de Verona's anonymous author, many Italian cities lifted their voices in praise of Verona, for "you are praised by Aquileia, Mantua, / Brescia, Pavia, Rome, and Ravenna."121 Finally, the author declares that "we shall sing" to God who gave Verona her saints implying that the audience will join the author in a song of praise.

Both authors cited above augmented the praise of their respective cities through amplificatio. Cicero identified amplificatio as a key technique for the "supreme virtue" of eloquence, while Quintilian argued that "the peculiar business of panegyric is to amplify or embellish its subjects." 122 This type of amplification often occurs within the text of a poem, but at times individual manuscripts visually enacted this rhetorical technique. Modena, Biblioteca capitolare, O.I.4, for instance, presently exists as a composite manuscript with texts ranging from a collection of papal letters to episcopal sermons to selections from Isidore's

115 VMC 1.28, ed. Pighi, 146.

116 VMC 1.31-33, ed. Pighi, 146.

117 VMC 1.40-42: "felix et beata Mediolanum ciuitas, / que habere tales sanctos defensores meruit, / precibus inuicta quorum permanet et fertilis," ed. Pighi, 146.

118 VMC 1.62-64: "ut dignetur custodire hanc urbem et regere / adque cunctis liberare ipsam de periculis / Ymnum regi modolanter cantemus altissimo," ed. Pighi, 147.

$119 V V$ 1.88: "Iam laudanda non est tibi, urbis in Auxonia / splendens pollens et redolens a sanctorum corpora, / opulenta inter centum sola in Italia," ed. Pighi, 154.

120 VV 1.55-57: "feliciem te Verona ditata et inclita, / qualis es circumuallata custodes sanctissimi, / que te defendet et expugna ab hoste iniquissimo," ed. Pighi, 153.

121 VV 1.91-92: "Nam te conlaudant Aquilegia, te conlaudant Mantua, / Brixia, Papia, Roma insimul Rauena [sic]," ed. Pighi, 154.

122 Quintilian, Institutio oratoria 3.7 (n. 1 above), 114-15. 
Decretals. ${ }^{123}$ Towards the end of this complex manuscript, however, a series of poems juxtapose the virtuous defense of a city and the downfall of another city immured in vice, creating a mise-en-page that visually strikes the reader quite apart from the specific contents of these texts.

Two distinct poems were written on fol. $154 \mathrm{v}$, with the first in the upper half of the verso now known as the "Song of the Watchmen of Modena" (one of the three so-called Carmina mutinensia), while the lower half transmits a copy of the Versus Romae in the same ninth- or tenth-century hand. ${ }^{124}$ After a brief comparative history of the risks and rewards of watchmen, citing the fall of Troy and the white goose's warning that saved Rome from the Gauls, the poet then smoothly switches to Modena's present adoration of Christ. Echoing Psalm 126:1, the poet exhorts the watchmen to "sing these songs of praise to Him as we keep watch," imploring Christ to watch over their city. ${ }^{125}$ A later tenth-century interpolator inserted two lines in a darker ink, entreating Christ not only to watch over Modena, but indeed to "be an impregnable wall for Your followers," to become the very wall of Modena itself. ${ }^{126}$ The poet concludes by returning to the young watchmen, exhorting them to "let your songs be heard through the walls," so that through the very walls themselves "may it echo: Keep watch!"127

The second twenty-four-line poem, the Versus Romae, is an invective against a ruined Rome. Composed in the eighth or ninth century, the Versus Romae addresses a personified Rome and bemoans her state of disintegration, both in terms of her crumbling infrastructure and the debased population that now dwells within her walls. ${ }^{128}$ The poem opens by declaring that "now, alas,

123 For a full description of the contents of this manuscript, which were copied between the ninth and eleventh centuries, see G. Vigarani, Inventario dei Manoscritti dell'Archivio Capitolare di Modena (Modena, 2003), 44-45; and M. W. Heil, "Bishop Leodoin of Modena and the Legal Culture of Late Ninth-Century Italy," Zeitschrift der Savigny-Stiftung für Rechtsgeschichte: Kanonistische Abteilung 103 (2017): 25-27. A digitized facsimile of this manuscript can be found here: https:/www.archiviodiocesano.mo.it/archivio/flip/ACMo-OI4/ (accessed 3 August 2020).

124 A. Roncaglia, "Il "Canto delle scolte modenesi," Cultura neolatina 8 (1948): 9. While scholars locate the exact time of this poem's composition with a range spanning the end of the ninth century and the first third of the tenth century, "The Song of the Watchmen of Modena" contains a firm terminus post quem to 881, as it refers to Santa Maria and San Giovanni chapels consecrated in that year.

125 Carmina mutinensia 1.19-20, ed. and trans. P. Godman, Poetry of the Carolingian Renaissance (London, 1985), 326-27.

126 Carmina mutinensia 1.25: "Tu murus tuis sis inexpugnabilis," ed. and trans. Godman, $326-27$.

127 Carmina mutinensia 1.38 and 1.42: "Vestra per muros audiantur carmina . . . Per muros 'eia!', dicat echo: 'vigila!'," ed. and trans. Godman, 326-27.

128 For a recent reassessment of this invective, complete with its complicated manuscript transmission, see Granier, “’̀ rebours des laudes civitatum” (n. 6 above), 131-54. 
submitted to slaves, Rome, you are falling apart." ${ }^{129}$ From the outset, the Versus Romae frames the constitution of the civic body — once the most noble, and now stemming from the lowest classes - as essential to the former glorious construction of Rome as well as to her now ruined physical state. After declaring that Rome's name and honor had been ceded to the Greeks as Roman natives now "tend Greek lands," the author then comes to the crux of the matter. ${ }^{130}$ Enlivened with the best of the former Roman population, Constantinople flourishes as the new Rome, a stark juxtaposition to the state of Rome, for "[y]our morals, as your walls, ancient Rome, are fallen."131 Even in her dilapidated condition, Rome obstinately persists in the vices of pride and greed. ${ }^{132}$ As the site of multiple Christian martyrs' deaths, the Versus Romae reminds Rome that she not only pierced the saints with cruel wounds, but even now "has the habit of selling their dead limbs" as relics for profit. ${ }^{133}$

This sharp juxtaposition between a virtuous, well-defended Modena and a ruined Rome finds further context on this same manuscript's fol. 157r. Three more poems in three different hands survive on a partially torn and somewhat water-damaged piece of parchment. Two poems begin with similarly phrased invocations for the fourth-century bishop of Modena, Geminianus, to defend the city's gates (portas) from the threatening Hungarians, who attacked the city around the turn of the tenth century. ${ }^{134}$ More intriguingly, the third poem on this folio has been interpreted as "un' Epigrafe murale." 135 This particular set of verses praises a late ninth-century bishop of Modena, Leodoin, for erecting defenses "while wretched madness oppressed istam patriam." ${ }^{36}$ He did so, according to this possible inscription, because he "desires to defend the cives with the proper guard." 137

129 Versus Romae, 1.1-2: "Nobilibus quondam fueras constructa patronis; / Subdita nunc servis heu male, Roma, ruis," ed. L. Traube, MGH, Poetae 3 (Berlin, 1886), 555.

130 Versus Romae 1.4-6: "Cessit et ad Graecos nomen honosque tuus / In te nobilium rectorum nemo remansit / Ingenuique tui rura Pelasga colunt," ed. Traube, 555-56.

131 Versus Romae 1.10: “Moribus et muris, Roma vetusta, cadis," ed. Traube, 556.

132 Versus Romae 1.17-18, ed. Traube, 556.

133 Versus Romae 1.22: "Vendere nunc horum mortua membra soles," ed. Traube, 556.

134 Carmina mutinensia 3.1 and 3.2, ed. L. Traube, MGH, Poetae 3 (Berlin, 1886), 706. In one particularly interesting diplomatic forgery from the tenth or eleventh century, a supposed charter of the Carolingian emperor Lothar I dated to August 842 describes the citizens of Modena as cives Geminiana. See Lothar I, no. 141 (unecht), ed. T. Schieffer, MGH, Diplomata 3 (Berlin, 1966), 316.

135 Roncaglia, "Il "Canto delle scolte modenesi"” (n. 124 above), 12.

136 Transcription in Roncaglia, "Il "Canto delle scolte modenesi"" (n. 124 above), 12: "Dum premeret patriam rabies miserabilis istam."

137 Transcription in Roncaglia, "Il "Canto delle scolte modenesi" (n. 124 above), 12: "Sed cives proprios cupiens defendere tectos." 
Civic discourse was not confined to the Italian peninsula. North of the Alps, the ninth-century monk and magister Abbo of St-Germain-des-Près devoted a lengthy poem to the year-long Viking siege of Paris from 885 to 886. ${ }^{138}$ Composed in 1,393 lines of dactylic hexameter divided into three books, Abbo classified his narrative as having a dual purpose: the first as a personal exercise in grammar, inspired by his reading of Virgil's Eclogues; the second so as "to provide a lasting example for the protectors of other cities." 139 In his poetic descriptions of destruction and fear, Abbo intermingled the emotions, the voice, and the fate of both the physical city and her citizens.

Abbo interweaves several classical tropes into his Bella Parisiacae urbis. ${ }^{140} \mathrm{He}$ opens the poem by beckoning Paris to "Speak keenly, Lutetia," and asks her to recall her founding, her natural surroundings, her walls, and her towers. Here, he intones such phrases in her voice as "I am a city, gleaming queen above the rest."141 Paris herself, so Abbo claims, wonders who can narrate the siege against her, and proclaims that Abbo should do so, for he saw it with his own eyes. ${ }^{142}$ More striking than classically-informed structural elements and topoi, the poet animates a personified Paris, and ties the physical city to the virtuous actions of her citizens. Abbo relates at length the various attacks Paris suffered, and it is through these attacks and the many trials of her inhabitants that the audience develops a clear sense of the ties that bound the citizens to each other and to their physical space.

These ties were particularly articulated in two moments: in periods of intense battle and in periods of intense communal devotional practices intended to counteract enemy attacks. Each time the city is assaulted, the attack reverberates throughout its citizenry. In one place, Abbo declares that "the city roars, its citizens (cives) quail, the bridges quaver;" in another, "the city quakes, its citizens (cives) shriek,

138 A. Adams and A. G. Rigg, "A Verse Translation of Abbo of St. Germain's Bella Parisiacae urbis," Journal of Medieval Latin 14 (2004): 1-68. For excellent analyses of Abbo's third book and his later reception, see P. Lendinara, "The Third Book of the Bella Parisiacae Urbis by Abbo of Saint-Germain-des-Prés and its Old English Gloss," Anglo-Saxon England 15 (1986): 73-89; and eadem, "Competing with Abbo: The Third Book of the Bella Parisiacae Urbis of Abbo of Saint-Germain and the Distigium of John of Garland," ANQ 4 (1991): 6-11. For the use of Abbo's work as evidence of siege warfare, see M. S. Fulton, Artillery in the Era of the Crusades: Siege Warfare and the Development of Trebuchet Technology (Leiden, 2018), 28-29.

139 BPU, prefatory letter to Gozelin: "Denique, huius eliminata directionis causa, aequum autumatur depromi geminas etiam opusculi inchoationis. Quarum siquidem prima fuerit causa exercitacionis (tunc etenim adhuc litteratoriae tyrunculus discipline Maronis proscindebam eglogas), altera vero mansuri aliarum tutoribus urbium exempli," ed. von Winterfeld, 77; trans. Adams and Rigg, 18.

140 BPU 1.1, ed. von Winterfeld, 79.

141 BPU 1.12: "Sum, polis, ut regina micans omnes super urbes," ed. von Winterfeld, 79; trans. Adams and Rigg, 21.

142 BPU 1.25, ed. von Winterfeld, 80. 
and trumpets blare." 143 Further on, as the tower comes under attack and "its citizens feel dread," not only does Abbo list the particularly spectacular leaders who fought the Vikings, but he also animates the defensive structures themselves: "The painted turrets grieve, stained by many wounds; / The bridge beams weep the strength of men, the floating dead. / No city street remained unstained by blood of men." 144 During another juncture, the tower itself was imbued with fear at the prospect of the Danish forces "pluck[ing] its eyes — its gates — away."145 In this way, Abbo imbued the very defensive structures with emotive, anthropic qualities, and added another layer of personification to the urban fabric.

In each of these cases, the terrified city and its terrified citizens respond to existential dread in a deliberate manner: by turning to the Virgin Mary and the sixthcentury bishop of Paris, Germain. At the moment of the death of Bishop Gozelin of Paris, Abbo interrupts his narrative and addresses his audience directly. Like Prudentius before him, Abbo first reminds his audience and auditors that "the city shines in honor, dedicated to / Great Mary, by whose aid we safely relish life."146 He then implores his audience to pray collectively to the Virgin, encouraging them by saying "let us give verbal thanks to her, and let us sing / Our hymns of peace to her, if we have strength, and let / High voice resound and sing her praises, for it is right." 147 Abbo then sets forth a hymn for "us" to sing, and clarifies who this "us" comprises: Lutetia's people. ${ }^{148}$ After praising the Virgin Mary as queen and mistress of the world, Abbo encourages his audience to praise Mary, "who deigned to free Lutetia's people (plebem) from fierce hands / And from the menace of the savage Danish sword."149 During another attack, as "the city mourns, the watch-towers fear, the walls shed tears," the citizens (cives) gather together to pray to St. Germain. Abbo makes clear that the entire civic body including "fine-looking youth and grey-haired old age" — all fear for their

143 BPU 1.64 and 1.91: "Urbs resonat, cives trepidant, pontesque vacillant . . Urbs pavitat, cives strepitant, et classica clamant," ed. von Winterfeld, 81 and 82; trans. Adams and Rigg, 24-25, with slight emendations.

144 BPU 1.253-55: "Haec depicta gemit vario sub vulnere rubra, / Ille virum luget vires obitusque fluentes. / Sanguine nulla via urbis adest intacta virorum," ed. von Winterfeld, 87; trans. Adams and Rigg, 31 .

145 BPU 1.431: "Quem turris metuit proprios sibi vellere ocellos," ed. von Winterfeld, 92; trans. Adams and Rigg, 36.

146 BPU 1.327-28: "Urbs in honore micat celsae sacrata Mariae, / Auxilio cuius fruimur vita modo tuti," ed. von Winterfeld, 89; trans. Adams and Rigg, 33.

147 BPU 1.329-31: "Hinc indicibiles illi, si forte valemus, / Reddamus grates, placidas reboemus et odas, / Vox excelsa tonet laudesque sonet, quia dignum," ed. von Winterfeld, 89; trans. Adams and Rigg, 33.

148 BPU 1.335, ed. von Winterfeld, 89.

149 BPU 1.334-35: “Quae saevis manibus Danum gladioque minace / Solvere Lutecie plebem dignata fuisti," ed. von Winterfeld, 89; trans. Adams and Rigg, 33, with slight emendations. 
lives. ${ }^{150}$ With one communal voice, the citizens and the city cry out to their saint. Not only does the gathered civic body sing hymns to their saintly intercessors for delivery, but the walls of the city itself "resound with Saint Germain's name."151

In the second book, St. Germain himself appears and circumambulates Paris. According to Abbo, an unnamed person crept into the church of St. Germain, fell asleep, and dreamed a vision of the saint. In this dream St. Germain "walked around the walls and sprinkled all the town" with holy water and promised hope to the townspeople before departing. ${ }^{152}$ Soon thereafter, Abbo relates that

... kindly Germain's body was borne round The city walls by his own men, and citizens Were following his guarded corpse and prayed to God Almighty with their prayer and with a tuneful voice. ${ }^{153}$

For his ultimately successful defense of the city, Paris proclaims at a later juncture that Germain was not only her king, shepherd, and sturdy friend, but also "my double-sharpened sword, my catapult, / Germain is my shield, my extending wall, my speedy bow." 154

Whether in Paris, Rome, Milan, or Verona, cities, saints, and citizens remain tightly intertwined in civic encomia and invectives, above all by their display of virtus. Early medieval authors not only drew attention to the physical fortifications that surrounded cities, but also encircled their citizens in a multifaceted form of defense that combined the physical walls, their saintly intercessors, and their own actions. The walls depicted in these poetic verses often reverberate and reecho the hymns as well as the cries of their citizens. As we shall see in the next section, the walls themselves could also be inscribed with words exhorting citizens to virtue.

150 BPU 1.386 and 388: "Urbs luget speculaeque timent et menia deflent . . pulchri iuvenes, sed et alba senectus," ed. von Winterfeld, 90-91; trans. Adams and Rigg, 35.

151 BPU 1.393-94 and 397: "Tum trepidant cives, cunctique vocant celebrandum / Germanum ... Menia Germani nomen recinunt," ed. von Winterfeld, 91; trans. Adams and Rigg, 35 .

152 BPU 2.123: "Unde rigans urbem graditur per menia circum," ed. von Winterfeld, 101; trans. Adams and Rigg, 46.

153 BPU 2.146-49: "Luce dehinc quadam dum gestabatur et almi / Militibus propriis corpus per moenia circum / Urbanis septum sectantibus omnipotentem / Perrogitando deum votis sub voce canora," ed. von Winterfeld, 102; trans. Adams and Rigg, 47.

154 BPU 2.384-86: "Rex meus ipse fuit pastorque, comes quoque fortis; / Hic ensis bisacutus adest meus, is catapulta, / Is clipeusque, patens murus, velox sed et arcus," ed. von Winterfeld, 108; trans. Adams and Rigg, 55, with slight emendations. 


\section{Inscribing Virtue: Mural Destruction, Construction, and Celebration in Ninth-century Rome}

In his Etymologiae, Isidore of Seville emphasized a crucial element of defense through his definitions of two different terms often used to designate walls. The first, moenia, are "so called because they protect (munire) the city, as if they were the bulwarks (munimentum) of the city, that is, the guardians," while the second, murus, "is so called from "defending' (munitio), as if the term were "to be defended' (muniri), because it defends and guards the inner parts of the city." 155 In addition to practical defensive considerations, Isidore hints at another reason why late antique and early medieval urban residents continued to maintain city walls. Not only were city walls a distinguishing feature between an urbs (or oppidium) and a vicus, but like the laws "city walls are said to be holy (sanctus)" because both laws and city walls "defend from wrong by imposing punishment." 156

Heavenly and earthly defense remained critical themes in extant descriptions of early medieval mural construction as well as in surviving mural inscriptions. Here, Rome may serve as a case study. According to the eighth- and ninthcentury papal biographies contained in the Liber Pontificalis, several popes aimed to restore the walls of Rome, though not all of them lived to see their projects completed. ${ }^{157}$ The most extensive description of papal mural construction occurs during the papacy of Leo IV (d. 855). ${ }^{158}$ This pope carried out at least two campaigns surrounding walls: one reconstructing and refortifying the city of Rome; the other constructing new walls around St. Peter's itself.

The first round of mural restoration occurred soon after Leo IV came to power in the immediate aftermath of a severe attack on Rome by Muslim raiders in

155 Isidore, Etymologiae 15.2.17-18, ed. Lindsay (n. 20 above), 161; trans. Barney et al. (n. 20 above), 306.

156 Isidore, Etymologiae 15.2.7-8 and 15.4.2, ed. Lindsay (n. 20, above), 161 and 166.

157 According to the second recension of Gregory II's biography, "at the start of his pontificate he ordered the burning of lime; he had issued a decree to restore this city's walls, commencing at St. Laurence's portico. He made some progress, but was prevented when various inconvenient tumults arose." See R. Davis, The Lives of the Eighth-Century Popes, AD 715817 (Liverpool, 1992), 3. Further on the Liber Pontificalis, see R. McKitterick, "Narrative Strategies in the Liber Pontificalis: The Case of St. Paul, doctor mundi, doctor gentium, and San Paolo fuori le mura," Rivista di Storia del Cristianesimo 10 (2013): 115-30; and now eadem, Rome and the Invention of the Papacy: The Liber Pontificalis (Cambridge, 2020). For archeological findings of the Leonine Wall, see S. Gibson and B. Ward-Perkins, "The Surviving Remains of the Leonine Wall," Papers of the British School at Rome 47 (1979): 30-57; S. Gibson and B. Ward-Perkins, "The Surviving Remains of the Leonine Wall, Part II: The Passetto," Papers of the British School at Rome 51 (1983): 222-39; R. Meneghini and R. Santangeli Valenzani, Roma nell'altomedioevo: Topografia e urbanistica della città dal Val $X$ secolo (Rome, 2004), 62-68; and Dey, The Aurelian Wall (n. 12 above), 271-78.

158 LP 105, ed. Duchesne, 2:106-34. 
846. ${ }^{159}$ The Liber Pontificalis describes the Romans as a broken people drained of all vigor, due to the dual blow of "the pontiff's sudden death and the plundering that had taken place in the holy churches and the territories of all the Romans." 160 As Roman dignitaries debated who might take Sergius II's papal seat, "suddenly the fame of the blessed prelate and also his value was manifested to all, broadcast through the whole city." 161 Together, all of Rome, "everyone from the last to first with one voice and one heart," declared their unanimous intention of Leo IV as their next pope and dragged him to the Lateran palace "with hymns and distinguished acclamations of praise." 162 As we see here, even before the extensive program of mural restoration, the Liber Pontificalis casts the death and destruction that struck the city as an impetus for all of the Romans "with one voice and one heart" to come together as citizens and identify the best among them as their future ecclesiastical leader and prospective securer of their city.

According to the Liber Pontificalis, Leo IV oversaw and directed a massive donation and building program throughout the city and churches of Rome, including the restoration of the city's walls. In 848 or 849 , Leo IV began "to treat the condition of the city of Rome and the restoration of the walls which by long old age were broken to age and utterly destroyed." 163 The stated motive for this project was Rome's defense and fear of future attack for, "if it stayed for long in this neglect and forgetfulness, they could easily with the Lord permitting it be captured or perhaps stormed by an enemy."164 The Liber Pontificalis claims that Leo IV himself "bustled about" amongst the walls as they were being rebuilt and fortified, "not simply staying at ground level but even going on his own feet along the walls and gates," so that the restoration would

159 LP 105, ed. Duchesne, 2:106. The Liber pontificalis labeled these raiders as Saracenis, and there remains some debate as to who precisely attacked Rome in 846. See L. M. Bondioli, "Islamic Bari between the Aghlabids and the Two Empires," in The Aghlabids and their Neighbors: Art and Material Culture in Ninth-Century North Africa, ed. G. D. Anderson, C. Fenwick, and M. Rosser-Own (Leiden, 2017), 470-90, at 479.

160 LP 105.5: "ex duobus casibus vel periculis, videlicet sive de repentina morte pontificis, sive de vastatione quae facta fuerat in ecclesiis sanctis cunctorumque finibus Romanorum," ed. Duchesne, 106; trans. Davis, 112.

161 LP 105.5: "confestim fama beatissimi praesulis simul et meritum ab omnibus patefacta est, totamque per urbem diffusa," ed. Duchesne, 107; trans. Davis, 112.

162 LP 105.6: "et ecce omnes a novissimo usque ad primum, una voce, una simul concordia ... cum hymnis laudibusque," "ed. Duchesne, 107; trans. Davis, 112.

163 LP 105.38: "tunc de Romanae urbis statu ac restauratione murorum, qui longo iam senio ad vetustatem infracti dirutique funditus videbantur," ed. Duchesne, 115; trans. Davis, 126.

164 LP 105.38: "si diu sub hac neglegentia sive oblivione consisteret, aut Domino permittente facilius ab hostibus aut capi aut forsitan expugnare potuissent," ed. Duchesne, 115; trans. Davis, 126. 
be completed as quickly as possible. ${ }^{165}$ This image of a bustling pope might have recalled for its audience not only the circumambulations of citizens during liturgical processions, but also the activity of other sainted figures patrolling the walls and protecting their city.

Out of "the greatest care and anxiety for the city of Rome," Leo IV ordered fifteen towers restored around the circuit of the city, with particular attention to the Portuensis Gate by the shore of the Tiber in anticipation of future naval attacks. ${ }^{166}$ These refortifications in and along the city's walls provided "both defense for the city of Rome (Romanae urbi defensionem) and for viewers (videntibus) no small wonder but a large one, as it was done with great prudence, subtle wisdom and honor." 167 Here, the Liber Pontificalis draws attention to the dual function of the city's wall, both as a defensive deterrent for any future enemy as well as a physical site imbued with virtue itself. Fear of future attacks also inspired Leo IV to encircle the borgo around St. Peter's into a new walled suburb, known as the civitas Leoniana. The Liber Pontificalis claims that Leo IV conceived of his plan to fortify the area around St. Peter's out of love and concern for the Roman people, for

while all the nobility of the Romans were lamenting exceedingly over what the wicked and malevolent Saracens had just recently inflicted in their looting, for fear they might subsequently cause worse damage if St. Peter the apostle's church were not speedily fortified with walls on all sides, this lovable pontiff began to have great distress for all the Romans, and anxiously to think how precisely he could remove so much sickness and fear from their hearts. ${ }^{168}$

The Liber Pontificalis situates the impetus for this new wall squarely in the initiative of Leo IV, with financial support and encouragement coming from the Carolingian emperor Lothar I (d. 855). ${ }^{169}$ However, an earlier capitulary of the Carolingian imperial court dated to October 846 claimed that it was not the

165 LP 105.39: "Quae denique omnia, ut cito fierent ad effectum decoremque perducta, praefatus vir apostolicus indifferenter non solum aequo residens, verum sane pedibus propriis per muros vel portas cum suis fidelibus discurrebat; quatinus in restauratione eorum mora ulla aut dilatio fuisset exorta," ed. Duchesne, 115; trans. Davis, 126.

166 LP 105.39: “maximam de Romana urbe curam ac sollicitudinem," ed. Duchesne, 115; trans. Davis, 126.

167 LP 105.40: “Quod noviter opus constructum et Romanae urbi defensionem prestat et videntibus non modicum sed grande miraculum, quam cum magna sapientia, subtili prudentia et onestate patratum est," ed. Duchesne, 115; trans. Davis, 127.

168 LP 105.68: "Quam ob rem dum universa Romanorum nobilitas, pro illa quam iamdudum depraedatione nefandi ac malivoli Saraceni intulerant, nimia lamentatione consisteret, ne deinceps, nisi ecclesia beati Petri apostoli muris undique munita citius foret, peiora valuissent committere, isdem amabilis pontifex magnam pro Romanis omnibus cepit abere angustiam et quo modo vel ordine ab eorum cordibus tantum potuisset rancore sive timore auferre anxius cogitare," ed. Duchesne, 123; trans. Davis, 139.

169 LP 105.69 ed. Duchesne, 123; trans. Davis, 140. 
pope, but instead the Frankish emperor and his people who spearheaded this effort to defend Rome. Whereas the Liber Pontificalis isolates the Romans' lamentations and fear as a driving force for the construction of these walls, the capitulary situates the so-called pagans' attack on Rome as punishment for the Franks' own sins and offences (quia pro peccatis nostris et offensionibus). ${ }^{170}$ The capitulary declares that Lothar himself decreed and sent an order "to the Apostolicus by our letters and envoys, that a very strong wall be built round St. Peter's church."171 Lothar demanded that the funds for this wall be collected throughout his kingdom, "so that so great a work, pertaining to the glory of all, may be completed with the help of all." 172 Such a collection would be accomplished by speaking to the kingdom's subjects via Frankish bishops, whom he ordered "to preach in their churches and cities, to persuade those who have no benefices yet have possessions and money, by exhorting and urging ... for the making of a wall round St Peter the apostle's church at Rome, since it is particularly fitting for children to honor their mother and, as far as they can, guard and defend her." 173 This remarkable clause personifies Rome as the Franks' vulnerable mother reaching out for protection, defense, and support from her transalpine children. Furthermore, this evocative image appears in a legal document theoretically sent throughout Francia to command preachers not only in their churches but also in their cities to persuade, exhort, and urge the Frankish people to donate to a massive mural building project hundreds of miles away. By defending this personified Rome through the creation of a murus firmissimus, the entire Frankish regnum will reap the collective glory.

Whether spearheaded by the pope or the emperor, the walls surrounding the civitas Leoniana were completed under Leo IV's "watchful and anxious" eye in 852. "Then at last," so the Liber Pontificalis narrates, Leo IV ordered a series of public processions and liturgical celebrations "so that this city (which is called Leonine from its founder's own name) might stand strong and firm forever." 174

170 Hlotharii capitulare de expeditione contra Sarracenos facienda 7, ed. A. Boretius and V. Krause, MGH, Capitularia regum Francorum 2 (Hannover, 1897), 66 (no. 203); trans. Davis, 139.

171 Hlotharii capitulare 7: "hoc Apostolico per litteras nostras et missos mandamus, ut murus firmissimus circa aecclesiam beati Petri construatur," ed. Boretius and Krause, 66; trans. Davis, 139.

172 Hlotharii capitulare 7: "ut tantum opus, quod ad omnium gloriam pertinet, omnium subsidio compleatur," ed. Boretius and Krause, 66; trans. Davis, 139.

173 Hlotharii capitulare 8: "ut praedicent in aecclesiis suis et civitatibus eis, qui sine beneficiis sunt et alodos atque peccunias [sic] habent, atque cohortando et incitando suadeant ... ad murum faciendum circa aecclesiam beati Petri apostoli Rome, eo quod hoc deceat plurimum, ut matrem filii honorent et, in quantum valent, tueantur atque defendant," ed. Boretius and Krause, 66-67; trans. Davis, 139.

174 LP 105.72: "ut praedicta civitas, que a proprio conditori sui nomine Leoniana vocatur, ut perpetualiter firma ac roborata consisteret," ed. Duchesne, 124; trans. Davis, 141. 
On the day before the vigils of Rome's spiritual founders, St. Peter and St. Paul, Leo first led a procession around the new walls. ${ }^{175}$ After chanting litanies and the psalter, he proceeded with all the clergy to "round the whole circuit of the walls, barefoot and with ash on their heads," while casting holy water "in every direction to hallow the wall as they crossed it." 176 Over the three new gates of the city at the Porta S. Peregrini (Porta Viridaria), the Posterula Castelli, and the postern facing the Saxon quarter, Leo IV stopped and recited a prayer imploring God to deliver the city from its sins and to ensure "this city which we have newly founded with thy assistance may ever remain safe from thy wrath and have new and manifold triumphs." 177 The pope then celebrated a mass "for the salus populi in the perpetual security and stability of the city," after which he distributed money and other "manifold gifts" to the assembled crowds and the Roman nobles. ${ }^{178}$ Finally, "throughout the whole city of Rome there were celebrations of unbounded gladness and unmeasured rejoicing." $" 179$

The echoes of prayers and celebrations recorded by the Liber Pontificalis have long faded. Fortunately, several inscriptions on the gates of the civitas Leoniana have survived, thus providing another means for the city to speak. ${ }^{180}$ A number of extant late antique and early medieval epigraphic inscriptions memorialize a particular individual's contributions to the construction or maintenance of a city's walls. ${ }^{181}$ Extant inscriptions attest to this complex nexus of defensive,

175 LP 105.41, ed. Duchesne, 115.

176 LP 105.72: "per totum murorum ambitum, nudis pedibus, cinerem portantes in capite, circuirent ... aquam transeuntes per murum sanctificationes gratia iactare omnimodis" ed. Duchesne, 124; trans. Davis, 142.

177 LP 105.73: "et hanc civitatem, quam noviter, te adiuvante, fundavimus, fac ab ira tua in perpetuum manere secura, et de ostibus, quorum causa constructa est, novos ac multiplices abere triumphos," ed. Duchesne, 124; trans. Davis, 142.

178 LP 105.74: "pro salute populi, civitatis incolumitate ac stabilitate perpetua honorifice decantavit," ed. Duchesne, 125; trans. Davis, 143.

179 LP 105.74: "sed et per totam Romanam urbem infinita gaudia et exultationes innumere celebrate sunt," ed. Duchesne, 125; trans. Davis, 143.

180 Gibson and Ward-Perkins, "The Surviving Remains of the Leonine Wall" (n. 157 above); and Gibson and Ward-Perkins, "The Surviving Remains of the Leonine Wall, Part II" (n. 157 above).

181 In addition to the inscriptions discussed below, it must be noted that such inscriptions can also appear as transcriptions in medieval manuscripts. For instance, the Chronicle of 754 contains two now lost epigraphic inscriptions in Latin hexameters commissioned by the Visigothic King Wamba to commemorate his restoration of the city of Toledo. According to the chronicle's anonymous author, one inscription was placed over the gates of the city, praising Wamba himself, while another inscription was placed on the defensive turrets that framed the city's gates imploring, "Vos, sancti domini quorum hic presentia fulget / Hanc urbem et plebem solito seruate fabore." See Crónica mozarabe de 754, c. 35, ed. J. E. López Pereira (Zaragoza, 1980), 54. For recent assessments of these inscriptions, see C. Martin, La géographie du pouvoir dans l'Espagne visigothique (Villeneuve d'Ascq, 2003), 219-20; and Dey, Afterlife of the Roman City (n. 15 above), 155-56. 
political, and symbolic functions surrounding city walls. Of course, not all inscriptions fall under the notion of civic discourse; indeed, just because words appear on a wall does not mean that they reflect wider conceptions of what it meant to be a citizen or live in a city. However, some inscriptions directly employ the terminology of civic discourse and, more specifically, refer to the process of building or restoring walls and encourage a specific response from those people who gaze upon their inscriptions. One of the inscriptions surrounding the civitas Leoniana implores travelers passing through its gates to gaze upon the wall, to marvel at its beautiful construction, and to praise "the triumphant prelate" (ovans praesul) who carried out this task. ${ }^{182}$ The inscription, composed in elegiacs, then turns to the city of Rome, stating that "I believe that the wars of evilminded men will never harm you, nor will your enemies triumph further." ${ }^{\text {"183 }}$ It finally begs a personified Rome, "head of the world, splendor, hope, golden Rome," to behold its new walls. ${ }^{184}$

When Rome came under attack again, Pope John VIII (d. 882) erected another walled enclosure around St. Paul's and labeled his new urbs Iohannipolis. Above the Porta Burgi of St. Paul, an inscription read "Here is the wall our savior and the undefeated portal that dissuades reprobates and welcomes the pious. Enter through here, oh illustrious ones, old and young who wear the toga, and blessed folk who seek the sacred threshold." ${ }^{185}$ As Angela Esposito has suggested, this new fortified urbs acted as an essential point in a complex network of ancient

182 Tituli ecclesiarum urbis Romae 16.8 (Ad portam viridariam), ed. E. Dümmler, MGH, Poetae 2 (Berlin, 1884), 664; and G. B. de Rossi, Inscriptiones Christianae Urbis Romae septimo seculo antiquiores 2.1 (Rome, 1888), 325 (no. 7); trans. Davis, 141-42, n. 108. At least three inscriptions were inscribed above the gates of the new Leonine wall at Porta S. Peregrini, Posterula Castelli, and Posterula Saxonum. According to Gibson and WardPerkins, the first two inscriptions are now lost, but were recorded as late as the early fifteenth century, while three fragments of the third inscription were discovered by Adriano Prandi in the 1950s and 1960s. See Gibson and Ward-Perkins, "The Surviving Remains of the Leonine Walls" (n. 157 above), 31-32. See also F. Marazzi, "Le 'città nouve' pontificie e l'insediamento laziale nel IX secolo," in La storia dell'Alto Medioevo Italiano (VI-X secolo) alla luce dell'archeologia: Convegno internazionale, Siena, 2-6 dicembre 1992, ed. R. Francovich and G. Noyé (Florence, 1994), 251-77.

183 Tituli ecclesiarum urbis Romae 16.8: "Credo malignorum tibi numquam bella nocebunt, / Neve triumphus erit hostibus ultra tuis," ed. Dümmler, 664; trans. Davis, 141-42.

184 Tituli ecclesiarum urbis Romae 16.8: "Roma, caput orbis, splendor, spes, aurea Roma," ed. Dümmler, 664; trans. Davis, 141-42.

185 Littere in porta burgi Sancti Pauli, lines 1-4: "Hic murus salvator [adest invic]taque porta / Quae reprobos ar[cet suscipi]t atque pios / Hanc proceres intra[te senes iuven]esque togati / Plebsque sacrata de[i limina sancta] petens," ed. K. Strecker, MGH, Poetae 4.2-3 (Berlin, 1923), 1016; trans. N. Camerlenghi, St. Paul's Outside the Walls: A Roman Basilica, from Antiquity to the Modern Era (Cambridge, 2018), 134, with emendations. Many thanks to Els Rose for her insights into the Latin of this particular inscription. 
and medieval fortifications that connected and protected Rome. ${ }^{186}$ Furthermore, as Nicola Camerlenghi has eloquently pointed out, "to the medieval mind, the apostolic affiliation added apotropaic value. Now St. Paul, his basilica and its fortified enclosure safeguarded the city and region as a whole." 187

These early medieval mural inscriptions on Rome's walls spoke, in a way, to those who passed by and passed through their gates. These inscriptions often directed their viewers to remember those ecclesiastical or secular leaders who had commissioned their creation and invoked God and his saints to protect those people who dwelled within their walls. More crucially, these inscriptions implored citizens and the personified city itself to gaze upon and reflect their walls, the same walls in which they would collectively gather together at times of crisis and times of celebration, and the same walls which would reverberate and reecho their prayers or quake in fear as they came under attack.

\section{Conchusion}

Some 900 miles north of Rome at the abbey of Corvey, an inscribed bronze panel long greeted those entering the church of Sts. Stephanus and Vitus with an invocation in four evenly spaced lines of capitalis monumentalis for God to "surround this city (civitatem istam) and let your angels guard its walls (muros eius)."188 According to one scholar, this large bronze inscription would have served "as a public proclamation at the entrance to the church," and "allow[ed] the prayer to be recited and to echo." 189 While such an interpretation is hard to substantiate, this invocation for God to surround the civitatem of Corvey and to protect muros eius reflects the broader civic discourse that has been the focus of this study. The gleam of the bronze and the elegant composition of the lettering point to the wealth of Corvey's benefactors and the skillful direction of its abbot. Yet the wording itself calls upon all of those who enter this city to gaze upon the inscribed letters, to recognize that they are entering a sacred space (as all walls, according to Isidore, are holy), and to consider how they might guard the walls of their own mental civitates.

186 A. Esposito, L'organizzazione della difesa di Roma nel medioevo, Miscellanea della società romana di storia patria 45 (Rome, 2003), 76-78.

187 Camerlenghi, St. Paul's Outside the Walls, 134.

188 Dated to the ninth century, the original panel $(173.5 \times 85.5 \mathrm{~cm})$ now lies inside the church in the emperor's gallery and a stone replica stands in its place in the westwork. For the image, text, and translation, see I. Weinryb, The Bronze Object in the Middle Ages (Cambridge, 2016), 110: “CIVITATEM ISTAM / TV CIRCVMDA DNE ET / ANGELI TVI CVSTO / DIANT MVROS EIVS." For an epigraphic study of this inscription, see R. Neumüllers-Klauser, "Die Westwerktafel der Kirche in Corvey: Ein Beitrag zur karolingischen Epigraphik," Westfalen 67 (1989): 127-138.

189 Weinryb, The Bronze Object in the Middle Ages, 110. 
Although we can no longer hear the processional hymns or defensive calls rebounding off surviving city walls, the early medieval city speaks to us still: through rhetorical compositions of praise, descriptions of processions, poetic accounts of destruction and defense, episodes in saints' lives, and words inscribed in the fabric of the city itself. Nor has this study addressed the full extent of the extant evidence. One could look more closely at archaeological findings detailing the upkeep of early medieval city walls or trace how medieval authors constructed the heavenly Jerusalem with their written words. One could also examine the development of Rogation ceremonies in Late Antiquity, and how crucial the cives were for such important figures as Sidonius Apollinaris, or the Carolingian adventus hymns composed for Metz, Orléans, and other Carolingian cities, which implored the collected body of citizens to gather, praise the arriving ruler, and celebrate his or her virtus together. ${ }^{190}$

The theme that connects each of the sites and texts treated in this article running through non-urban spaces, through public processions and civic personifications, through rhetorical praises and censures of the city, and through the focus on the formation of the civitas Leoniana - sounds through the voices of citizens. Often, it is hard to access the late antique and early medieval individual, particularly if the individual in question held no significant office or public power. However, attention to civic discourse allows the modern reader to access how late antique and early medieval authors urged citizens of particular cities to act; these are prescriptive texts and mental images, designed to persuade. The repeated and emphatic exhortations to civic virtue also suggest how the city was perceived as incapable of functioning - particularly during times of looming threats — without the collective body parading together, praying together, and singing hymns and psalms with one voice.

\section{Utrecht University \\ m.l.welton@uu.nl}

Keywords: civic discourse, virtue, rhetoric, personification, city walls, inscriptions

\footnotetext{
190 For a recent analysis and relevant bibliography of the early development of the Rogations, see Ristuccia, Christianization and Commonwealth in Early Medieval Europe (n. 99 above).
} 